\title{
Investigation of the Antimicrobial Activity and in Vivo Cytotoxicity of Diospyros malabarica (Desr.) Kostel. Fruit Extracts
}

Razib Datta Shubhra', Shakil Ahmed Polash ${ }^{1}$, Md. Monir Hossain ${ }^{1}$, Amir Hamza', Md. Mehedi Hasan Tushar ${ }^{1}$, Tanushree Saha' ${ }^{2}$, Md. Ashraful Hasan ${ }^{3}$, Md. Maniruzzaman Sikder ${ }^{4}$, Nuhu Alam ${ }^{4}$, Zinia Islam¹, Md. Sharif Hossain ${ }^{1}$, Satya Ranjan Sarker ${ }^{1 *}$

${ }^{1}$ Department of Biotechnology and Genetic Engineering, Jahangirnagar University, Savar, Bangladesh; ${ }^{2}$ Department of Textile Engineering, Dhaka University of Engineering and Technology, Gazipur, Bangladesh; ${ }^{3}$ Department of Biochemistry and Molecular Biology, Jahangirnagar University, Savar, Bangladesh; ${ }^{4}$ Department of Botany, Jahangirnagar University, Savar, Bangladesh

Correspondence to: Satya Ranjan Sarker, satya.sarker@bgeju.edu.bd

Keywords: Diospyros malabarica (Desr.) Kostel., Antibacterial Activity, Trypan Blue Assay, Cell Tox ${ }^{\mathrm{TM}}$ Green Assay, In Vivo Cytotoxicity

Received: June 20, $2021 \quad$ Accepted: July 30, $2021 \quad$ Published: August 3, 2021

Copyright $\odot 2021$ by author(s) and Scientific Research Publishing Inc.

This work is licensed under the Creative Commons Attribution International License (CC BY 4.0).

http://creativecommons.org/licenses/by/4.0/

(c) (i) Open Access

\section{ABSTRACT}

Mankind is facing an unprecedented threat of existence due to the antibiotic resistance developed by bacteria. The unripe fruits of Diospyros malabarica (Desr.) Kostel. (family: Ebenaceae) can be considered as one of the natural sources to tackle this issue. The present study is designed to assess the antimicrobial activity of $D$. malabarica seed and flesh extracts. Herein, $D$. malabarica extracts were prepared using polar solvents (i.e., water and $70 \%$ ethanol) and their antimicrobial activity as well as in vivo toxicity was investigated. Their antibacterial activity was investigated against gram positive (Bacillus subtilis) and gram negative (Escherichia coli DH5a, and Salmonella typhi) bacteria at different time points. All the extracts showed the highest antibacterial activity after 2 hours of incubation. The aqueous seed extract showed the maximum zone of inhibition (i.e., $\sim 13 \mathrm{~mm}$ ) against Bacillus subtilis with a minimum inhibitory concentration (MIC) value of $2 \mu \mathrm{g} / \mu \mathrm{l}$. The antibacterial propensity was also confirmed through trypan blue dye exclusion assay, CellTox $^{\mathrm{TM}}$ Green assay, and lipid peroxidation (LPO) assay. On the other hand, the ethanolic seed extract demonstrated higher antifungal activity through inhibition of mycelial growth. All the extracts showed excellent hemocompatibility against both human and rat red blood cells (RBCs). They also did not show any toxicity to rat liver and kidneys. Taken together, this study demonstrates that the aqueous and ethanolic extracts of $D$. malabarica seed and flesh could be an effective source of natural antimicrobial agents with no cytotoxic activity. 


\section{INTRODUCTION}

Medicinal plants are the rich source of therapeutically important compounds that provide them with the ability to show different bioactive properties [1]. Because of the immense potential of plants and plant derived products to improve the health care sector, researchers are now focusing on phytomedicine to tackle the menace of multidrug resistant bacteria. Furthermore, the toxicity of chemically synthesized drugs makes plant-based medicines (i.e., phytomedicine) as suitable alternatives [2]. During the ancient times, infectious diseases caused by different pathogenic microorganisms were the leading cause of death all over the world. Mankind used plants or plant-derived medicines to cure from illness as well as to prevent themselves from diseases $[3,4]$. At present, the emergence of multidrug-resistant bacteria is causing millions of casualties every year in the world [5]. In the modern medical treatment, huge consumption of chemically synthesized antibiotics is not only preventing the infectious diseases but also paving the way to generate antibiotic resistant bacteria that is one of the biggest threats to global health, agriculture, food security, and development [3]. Furthermore, the synthetic antibiotics have various side effects [6, 7] that have necessitated the pursuit of natural antibacterial agents. In addition, pathogenic fungi are highly responsible for hampering the production and quality of agricultural crops, fruits, and vegetables [7, 8] besides causing diseases to human. Recent studies revealed that fungal attack on rice plants causes $11 \%-15 \%$ yield loss annually [9]. On the other hand, more than 300 fungal metabolites are known to cause allergic reactions and diseases to the consumers [8]. Different commercially available chemically synthesized fungicides are effective for fungal growth inhibition. However, they are highly toxic to human health as well as hazardous for the environment [10]. Hence, there is an urgent need to discover new antimicrobial compounds against pathogenic microbe-induced diseases. Many plants or plant-derived products having antimicrobial properties can effectively provide a wide range of protection against pathogenic bacteria or fungi as well as can be an effective alternative to the chemically synthesized antibiotics or fungicides $[3,4$, $7,8]$.

Since plant extracts contain various bioactive molecules including secondary metabolites and many people rely on herbal medicine as their primary healthcare needs, it is one of the major concerns to investigate the biocompatibility of plant extracts [11]. Hemolysis activity of the plant extracts is an important parameter to investigate their toxicological effects, because it provides primary information about their interaction with biological entities at the cellular level [1]. Besides blood cells, due to the diverse chemical properties of plant extracts, they can interact with other body organs (i.e., liver, kidney, lung, spleen, and heart) and result in adverse effects [11]. Hence, the investigation of the biocompatibility of plant extracts is crucial, because various secondary metabolites produced by plants can be a novel agent for new drug leads [12].

Diospyros malabarica (Desr.) Kostel. (family: Ebenaceae) is a lowland rainforest species [13]. It is medicinally important, because different parts of it contain anti-diabetic, anti-diarrheal, and anti-inflammatory properties $[14,15]$. For example, the seeds of the immature fruits of $D$. malabarica were traditionally used for the treatment of ulcer, diarrhea, and chronic dysentery [13-15]. Although several studies on different parts of $D$. malabarica have been performed, the extensive antimicrobial activity and in vivo cytotoxicity of D. malabarica seed and flesh are yet to be investigated.

The present study focused on the investigation of antimicrobial activity as well as in vivo biocompatibility of different parts of $D$. malabarica fruit. Herein, we prepared $D$. malabarica seed and flesh extracts using water and $70 \%$ ethanol (i.e., polar solvent). The antibacterial activity in terms of zone of inhibition (ZOI) in millimeter ( $\mathrm{mm}$ ), minimum inhibitory concentration (MIC) value, trypan blue dye exclusion assay, and CellTox ${ }^{\mathrm{TM}}$ Green cytotoxicity assay of $D$. malabarica seed and flesh extracts was performed against gram negative (i.e., S. typhi and E. coli $\mathrm{DH} 5 \alpha$ ) and gram positive (i.e., B. subtilis) bacterial strains. The mechanism of antibacterial activity was also investigated through lipid peroxidation assay. On the other hand, antifungal activity was investigated against Pestatotiopsis microspora, Botrytis cinerea, and Fusarium oxysporum. The hemocompatibility of the extracts was tested using human and rat RBCs. The in vivo cytotoxicity of extracts was investigated using animal model (i.e., rat). 


\section{MATERIALS AND METHODS}

\subsection{Chemicals and Reagents}

Absolute ethanol, EDTA, trichloroacetic acid (TCA), and $\mathrm{HCl}$ were purchased from Merck, Germany. Sodium hydroxide $(\mathrm{NaOH})$ was bought from Ashland Inc., USA. Agar powder was collected from Titan Biotech Ltd., India. Peptone, yeast extract powder, dextrose, and sodium chloride were purchased from UNI-CHEM, China. Hydrogen peroxide $\left(\mathrm{H}_{2} \mathrm{O}_{2}\right)$, ketamine/xylazine, and thiobarbituric acid (TBA) were bought from SIGMA ALDRICH, Germany. Potassium chloride $(\mathrm{KCl}), \mathrm{Na}_{2} \mathrm{HPO}_{4}$, and $\mathrm{KH}_{2} \mathrm{PO}_{4}$ were obtained from Scharlab, Spain. Propiconazole was purchased from Syngenta, Australia. Ascorbic acid was purchased from VEGA, China and trypan blue was procured from Alfa Aesar, United Kingdom. CellTox $^{\mathrm{TM}}$ Green dye was bought from Promega, USA. The biochemical analysis kits for serum AST, ALT, and $\gamma$-GT analysis were purchased from Vitro Scient, Egypt and the serum creatinine determination kit were bought from Crescent Diagnostics, the Kingdom of Saudi Arabia.

Escherichia coli DH5a (ATCC 25922), Bacillus subtilis RBW (ATCC 6051), and Salmonella typhi (ATCC 14028) were collected from the department of Biotechnology and Genetic Engineering, Jahangirnagar University, Savar, Dhaka 1342, Bangladesh. The fungal strain Pestalotiopsis microspora (ATCC 26275), Botrytis cinerea (ATCC 26943), and Fusarium oxysporum (ATCC 62705) were collected as pure culture from the Plant Pathology Laboratory, Department of Botany, Jahangirnagar University, Savar, Dhaka 1342, Bangladesh. Fifteen Wister female rats (weighing between 90 and $120 \mathrm{~g}$ ) were obtained from the Department of Pharmacy, Jahangirnagar University, Dhaka, Bangladesh.

\subsection{Sample Collection and Preparation}

The unripe fruits of $D$. malabarica (Desr.) Kostel. were collected from the local market of Mymensingh, Bangladesh $\left(24.7471^{\circ} \mathrm{N}, 90.4203^{\circ} \mathrm{E}\right)$ and brought to the laboratory. The fruits were washed properly with distilled water. Subsequently, the flesh and seed parts of the fruits were separated carefully and cut into small pieces. Both the flesh and seed parts were then dried in a hot air oven at $60^{\circ} \mathrm{C}$. Thereafter, the dried chips were ground into coarse powder and stored in sealed container for further analysis.

\subsection{Preparation of Crude Extract and Fractionation}

Crude extracts and their stock solutions were prepared according to our previously established protocol [16-21]. Briefly, $5 \mathrm{~g}$ of powdered materials of both seed and flesh were taken in clean conical flasks and soaked in $100 \mathrm{ml}$ of the respective solvents. Our previously published research on the phytochemical constituents of $D$. malabarica seed and flesh indicated that $D$. malabarica fruit is a rich source of polar phytochemicals [16], that is why, we used only polar solvents (distilled water and $70 \%$ ethanol) in the present study. After that, the flasks were kept in a water bath for 72 hours upon gentle shaking at $120 \mathrm{rpm}$. The crude mixtures were then filtered by Whatman No.1 filter paper and the extracts were concentrated in a petri plate through evaporation [22]. When the evaporation was completed, the plates containing extracts were stored in a dry and cool place for further analysis. Finally, different concentrations of the extract sample were prepared using $0.9 \% \mathrm{NaCl}$ solution.

\subsection{Antibacterial Activity Assay}

\subsubsection{Determination of Minimum Inhibitory Concentration (MIC)}

The MIC value was measured to detect the minimum amount of the extracts of $D$. malabarica seed and flesh required to inhibit the growth of bacteria. The MIC value of the extracts was determined through broth dilution method as described previously $[17,18]$. Briefly, $990 \mu \mathrm{l}$ of Luria Bertani (LB) medium was inoculated with $10 \mu \mathrm{l}$ of overnight grown respective bacterial cultures (optical density, OD: 1.5 - 1.7). Different amounts of the extracts (i.e., 0.25, 0.5, 1, 1.5, 2, 2.5, 3, 3.5, 4, 4.5, 5, 7.5, and $10 \mu \mathrm{g} / \mu \mathrm{l}$ ) were added into the bacterial cultures and incubated for 2 hours at $37^{\circ} \mathrm{C}$ in an incubator upon shaking at $120 \mathrm{rpm}$. The absorbance of all the cultures was taken at $600 \mathrm{~nm}$ using a UV-visible Spectrophotometer (Optizen POP, 
Korea). The experiment was performed in triplicate $(n=3)$.

\subsubsection{Determination of Zone of Inhibition (ZOI)}

The antimicrobial activity of $D$. malabarica seed and flesh extracts was determined by disk diffusion method as described previously [23, 24]. Briefly, bacterial strains (i.e., E. coli DH5a, B. subtilis RBW, and $S$. typhi) were cultured in LB medium at $37^{\circ} \mathrm{C}$ and $120 \mathrm{rpm}$ overnight. Then $100 \mu \mathrm{l}$ of the respective bacterial culture (OD: 1.8 - 1.9) was taken and spread uniformly on LB agar plates. Metrical filter paper disks (diameter $5.55 \mathrm{~mm}$ ) containing different amounts of plant extracts (i.e., 0.2, 1, 2, 3, and $4 \mathrm{mg}$ ) were placed on the LB agar plates containing uniformly spread bacteria. The same experiment was performed using $0.9 \% \mathrm{NaCl}$ as negative control. The $\mathrm{LB}$ agar plates were then incubated overnight at $37^{\circ} \mathrm{C}$ for the optimum growth of bacteria. Finally, the antibacterial activity of $D$. malabarica seed and flesh extracts was determined by the presence of clear zones surrounding the disks which confirmed the inhibition of bacterial growth. The diameter of the clear zones was measured using slide calipers at different time points.

\subsubsection{Trypan Blue Dye Exclusion Assay}

Trypan blue dye exclusion assay was performed for the bacteria treated with $D$. malabarica seed and flesh extracts according to our previously published protocol with little modifications [23-25]. Briefly, 4 $\mathrm{mg}$ of plant extracts was mixed separately with $50 \mu \mathrm{l}$ of diluted overnight grown culture (OD: 1.3 - 1.4) of the respective bacterial strains (i.e., E. coli DH5a, B. subtilis $\mathrm{RBW}$, and $S$. typhi) and incubated at $37^{\circ} \mathrm{C}$ and $120 \mathrm{rpm}$ for 2 hours. The plant extracts treated bacterial cultures were then mixed with freshly prepared $0.4 \%$ trypan blue solution at a ratio of $1: 1$ and incubated for $15 \mathrm{~min}$ at room temperature. Twenty microliter $(20 \mu \mathrm{l})$ of the mixture was taken on glass slides and imaged for live and dead bacterial cells using a phase contrast microscope (Olympus BX50 Fluorescence Microscope, Olympus, Japan) at 40× magnification. The experiments were performed in triplicate $(n=3)$.

\subsubsection{Cell Tox ${ }^{\mathrm{TM}}$ Green Assay}

CellTox ${ }^{\mathrm{TM}}$ Green assay was accomplished according to our previously published paper [23]. Briefly, overnight grown bacterial culture was diluted with LB broth and the concentration was set to $1 \times 10^{7}$ $\mathrm{CFU} / \mathrm{ml} .4 \mathrm{mg}$ of the extracts of $D$. malabarica seed and flesh was mixed separately with $100 \mu \mathrm{l}$ of the respective bacterial cultures. Then $800 \mu \mathrm{l}$ of fresh LB broth was added to mixtures and the tubes were incubated at $37^{\circ} \mathrm{C}$ and $120 \mathrm{rpm}$ for 2 hours. After the incubation, $2 \mu \mathrm{l}$ of CellTox ${ }^{\mathrm{TM}}$ Green reagent was mixed properly with plant extracts treated bacterial culture and incubated for another $30 \mathrm{~min}$ at room temperature in the dark. Twenty microliter $(20 \mu \mathrm{l})$ of the CellTox ${ }^{\mathrm{TM}}$ Green labelled bacterial culture was kept aside to observe the dead cells under fluorescence microscope (Olympus BX50 Fluorescence Microscope, Olympus, Japan). The remaining bacterial suspension was used to measure the fluorescence intensity of the dead bacterial cells using Spectrofluorophotometer (SHIMADZU RF-6000, Japan) at $490 \mathrm{~nm}$. Control tubes containing plant extracts, cells, and media were run without CellTox ${ }^{\mathrm{TM}}$ Green alongside the treatment groups. All experiments were carried out in triplicate $(n=3)$.

\subsubsection{Lipid Peroxidation Assay}

The lipid peroxidation (LPO) potential of $D$. malabarica seed and flesh extracts was investigated according to our previously published protocol [23-25]. Briefly, $200 \mu \mathrm{l}$ of the overnight grown bacterial cultures (OD: 1.4 - 1.6) was mixed separately with $4 \mathrm{mg}$ of each of the plant extracts. After that, $500 \mu \mathrm{l}$ of $10 \%$ trichloroacetic acid (TCA) was added and the mixtures were incubated for $30 \mathrm{~min}$ at room temperature before centrifuging at $10,416 \times \mathrm{g}$ for 50 minutes to separate the dead cells and insoluble cellular components. The supernatant containing malondialdehyde was then collected in a fresh tube and mixed with freshly prepared $1 \mathrm{ml}$ of $0.67 \%$ thiobarbituric acid (TBA) solution (pre-warmed) and incubated in a hot water bath for 10 minutes to facilitate the formation of malondialdehyde-TBA adduct. After cooling down to room temperature, the absorbance of the malondialdehyde-TBA adduct was measured by UV-vis spectrophotometer (Specord 205 , Analytik Jena, Germany) at $532 \mathrm{~nm}$. The whole experiment was performed 
in triplicate $(n=3)$.

\subsection{Antifungal Activity Assay}

Antifungal activity of $D$. malabarica seed and flesh extracts against Pestalotiopsis microspora, Botrytis cinerea, and Fusarium oxysporum was investigated through poisoned food method [8]. Briefly, autoclaved potato dextrose agar $(\mathrm{PDA})$ medium $\left(60^{\circ} \mathrm{C}\right)$ containing $1 \mathrm{ml}$ of each of the different extracts and lactic acid (as antibacterial agent) were poured onto separate petri dishes. PDA medium with fungicide propiconazole $(500 \mathrm{ppm})$ was used as positive control and PDA medium with $0.9 \% \mathrm{NaCl}$ was used as negative control. Lactic acid was used as antibacterial agent to prevent fungal-borne bacteria. After solidification, mycelia of the tested fungi were placed on the center of the dishes. The petri dishes were sealed with parafilm to prevent cross contamination with other fungi and incubated at $30^{\circ} \mathrm{C} \pm 2^{\circ} \mathrm{C}$ for 72 hours. After incubation, the diameters of fungal growth in control and treated plates were measured. The experiment was performed in triplicate $(n=3)$. The percentage mycelial inhibition (PMI) for all extracts of $D$. malabarica seed and flesh was determined using the following formula:

$$
\operatorname{PMI}(\%)=\frac{C-A}{C} \times 100
$$

where, $C=$ mycelial growth in millimeter in negative control plate;

$A=$ mycelial growth in millimeter in plant extract treated plate.

\subsection{Hemocompatibility Assay}

Hemocompatibiliity assay of $D$. malabarica seed and flesh extracts was performed according to our previously published paper with few modifications [5, 23, 25]. Briefly, fresh blood was collected from healthy human as well as rat in separate tubes containing EDTA (10\%). The tubes were centrifuged at 775 $\times \mathrm{g}$ for $10 \mathrm{~min}$ to separate the RBCs from serum. The serum was discarded, and the RBCs pellet was resuspended in phosphate buffered saline (PBS) and centrifuged again at $775 \times \mathrm{g}$ for $10 \mathrm{~min}$. After discarding the supernatant, the RBCs pellet was washed trice with $\mathrm{NaCl}(150 \mathrm{mM})$ solution at $775 \times \mathrm{g}$ for 5 minutes. Finally, Different concentrations of plant extracts (i.e., 1, 2, and $4 \mathrm{mg}$ ) and $100 \mu \mathrm{l}$ of RBCs were mixed and incubated at $37^{\circ} \mathrm{C}$ for 30 minutes with gentle shaking. The tubes were then centrifuged at $1377 \times \mathrm{g}$ for 10 min. The supernatant was separated, and the absorbance was measured at $570 \mathrm{~nm}$. RBCs incubated with PBS, and water were used as negative and positive control, respectively. The percentage of hemolysis was calculated using the following formula:

$$
\text { Hemolysis }(\%)=\left(\frac{\text { Absorbance of the sample }- \text { Absorbance of negative control }}{\text { Absorbance of positive control }- \text { Absorbance of negative control }}\right) \times 100
$$

To calculate the amount of extracts required to lyse $50 \%$ of RBCs (i.e., $\mathrm{HC}_{50}$ value), the percentage of hemolysis was plotted against the concentration of extracts to draw a regression line. The concentration of the extracts that brought about $50 \%$ hemolysis (i.e., $\mathrm{HC}_{50}$ value) was calculated from the following equation:

$$
Y=a * X+b
$$

Here, $Y=50 \%, X=$ the concentration of the extracts at which $50 \%$ hemolysis occurred, $a=$ coefficient, and $b=$ constant.

\subsection{Inhibition of $\mathrm{H}_{2} \mathrm{O}_{2}$ Mediated Hemolysis}

Erythrocyte hemolysis inhibition assay was performed according to Pareja et al. with little modifications [26]. Briefly, $6 \mathrm{ml}$ of blood was collected from a healthy individual and centrifuged at $538 \times \mathrm{g}$ for 10 min. The supernatant was discarded, and the pellet was washed thrice with $0.2 \mathrm{M}$ before resuspending in PBS. The pellet of erythrocytes $(200 \mu \mathrm{l})$ was diluted with $4 \mathrm{ml}$ of PBS to prepare $5 \%$ suspension. Plant extracts was also diluted with PBS. In this experiment, ascorbic acid was used as standard negative control. 
Different concentrations of plant extracts (i.e., $0.25,0.5,1,2$, and $4 \mathrm{mg}$ ) were mixed with $\mathrm{H}_{2} \mathrm{O}_{2}(200 \mu \mathrm{l} ; 1$ $\mathrm{M}$ ), and $\mathrm{RBC}$ suspension $(400 \mu \mathrm{l})$ and incubated at $37^{\circ} \mathrm{C}$ for $240 \mathrm{~min}$ with gentle shaking. After incubation, the tubes were centrifuged at $1377 \times \mathrm{g}$ for $10 \mathrm{~min}$. The supernatant was then separated, and the absorbance was measured at $540 \mathrm{~nm}$. Here, $\mathrm{RBCs}$ incubated with only $\mathrm{H}_{2} \mathrm{O}_{2}(1 \mathrm{M})$ was used as positive control. The percentage of inhibition of $\mathrm{H}_{2} \mathrm{O}_{2}$ induced hemolysis was calculated using the following formula:

$$
\text { Inhibition }(\%)=\left(\frac{\text { Absorbance of control }- \text { Absorbance of the sample }}{\text { Absorbance of control }}\right) \times 100
$$

The percentage of the inhibition of $\mathrm{H}_{2} \mathrm{O}_{2}$ induced hemolysis was plotted against the concentration of extracts which provided a regression line. The concentration of the extract that inhibited $50 \%$ of $\mathrm{H}_{2} \mathrm{O}_{2}$ induced hemolysis (i.e., $\mathrm{IC}_{50}$ value) was calculated from the following equation:

$$
Y=a * X+b
$$

Here, $Y=50 \%, X=$ the concentration of the extract that inhibits $50 \%$ of $\mathrm{H}_{2} \mathrm{O}_{2}$ induced hemolysis, $a=$ coefficient, and $b=$ constant.

\subsection{In Vivo Cytotoxicity Assay}

\subsubsection{Acute Oral Toxicity Testing}

Fifteen Wister female rats were divided into 5 groups $(n=3)$. The rats were housed in a hygienic environment under controlled temperature $\left(23^{\circ} \mathrm{C} \pm 2^{\circ} \mathrm{C}\right)$ and humidity $(55 \% \pm 7 \%)$ and allowed to acclimatize for a week before oral administration. According to OECD test guideline (up and down procedure), the rats were administered $200 \mathrm{mg} / \mathrm{kg}$ (i.e., small dose) and $400 \mathrm{mg} / \mathrm{kg}$ (i.e., high dose) of the aqueous seed and aqueous flesh extracts, respectively, of $D$. malabarica prepared in PBS every $24 \mathrm{~h}$ for 14 days [27]. The control rat group was administered with the PBS only without plant extracts. Food and water intake, physical appearance, disease occurrence, and body weight were monitored during the period of administration. After 14 days, all the rats were anaesthetized with $0.3 \mathrm{ml} / 250 \mathrm{gm}$ ketamine/xylazine $(100 \mathrm{mg} / \mathrm{ml}$ Ketamine $+20 \mathrm{mg} / \mathrm{ml}$ xylazine). Blood $(\sim 3 \mathrm{ml})$ was drawn from all the rats and centrifuged at $538 \times \mathrm{g}$ for $10 \mathrm{~min}$ at room temperature to separate the serum. The serum samples were stored at $-20^{\circ} \mathrm{C}$ for further biochemical analysis.

\subsubsection{Investigation of Liver and Kidney Function Biomarkers}

To determine whether the aqueous extracts of $D$. malabarica seed and flesh (as they have maximum antibacterial activity) have any toxic effects to rat tissues, the concentration of several enzymes whose level usually get hiked once there is any damage in the liver and kidneys were measured. The level of liver function biomarkers (serum aspartate aminotransferase (AST), alanine aminotransferase (ALT), gamma-glutamyltransferase $(\gamma$-GT)), and kidney function biomarker (creatinine) of the experimental and control rats were quantified according to the manual provided with the commercial reagents by using spectrophotometer (Shimadzu, Kyoto, Japan). Herein, the protocol has been provided in the following sections:

\section{1) Liver function biomarkers}

\section{a) Determination of serum alanine transaminases (ALT) activity}

The level of serum ALT activity was measured according to previously established protocol [28]. Briefly, $100 \mu \mathrm{l}$ serum sample was mixed with $1000 \mu \mathrm{l}$ reagent in a quartz cuvette. The absorbance of the sample and the standard against the reagent blank were measured at $340 \mathrm{~nm}$ at different time points (i.e., $1,2$, and $3 \mathrm{~min})$. The change in the absorbance per minute $(\Delta A / \mathrm{min})$ was determined from the linear portion of the reaction curve and the concentration of ALT was calculated by using the following formula:

$$
\operatorname{ALT} \text { activity }\left(\frac{\mathrm{U}}{\mathrm{L}}\right)=\frac{\Delta A}{\min } \times 1375\left(30^{\circ} \mathrm{C}\right)
$$

Here, $\Delta A=$ Average absorbance of the sample in different time points (i.e. 1, 2, and 3 minutes). 


\section{b) Estimation of serum aspartate transaminase (AST) activity}

The level of serum AST activity was measured according to previously established protocol $[28,29]$. Briefly, $100 \mu \mathrm{l}$ serum sample was mixed with $1000 \mu \mathrm{l}$ reagent in a quartz cuvette. The absorbance of the sample and the standard against the reagent blank were measured in $340 \mathrm{~nm}$ at different time points (i.e., $1,2$, and $3 \mathrm{~min})$. The change in absorbance per minute $(\Delta A / \mathrm{min})$ was determined from the linear portion of the reaction curve and the AST concentration was calculated by using the following formula:

$$
\operatorname{AST} \text { activity }\left(\frac{\mathrm{U}}{\mathrm{L}}\right)=\frac{\Delta A}{\min } \times 1750\left(30^{\circ} \mathrm{C}\right)
$$

Here, $\Delta A=$ Average absorbance of the sample in different time points (i.e. 1, 2, and 3 minutes).

c) Measurement of serum $\gamma$-glutamyltransferase ( $\gamma$-GT) activity

The level of serum $\gamma$-GT activity was measured according to previously established protocol [30]. Briefly, $50 \mu \mathrm{l}$ serum sample was mixed with $1000 \mu \mathrm{l}$ reagent in a quartz cuvette. The absorbance of the sample and the standard against the reagent blank were measured at $405 \mathrm{~nm}$ at different time points (i.e., $1,2$, and $3 \mathrm{~min})$. The change in absorbance per minute $(\Delta A / \mathrm{min})$ was determined from the linear portion of the reaction curve and the $\gamma$-GT concentration was calculated by using the following formula:

$$
\gamma \text {-GT activity }\left(\frac{\mathrm{U}}{\mathrm{L}}\right)=\Delta A 405 \frac{\mathrm{nm}}{\min } \times 400
$$

Here, $\Delta A=$ Average absorbance of the sample in different time points (i.e., 1, 2, and $3 \mathrm{~min}$ ). One international unit $(\mathrm{U})$ is defined as the amount of enzyme that catalyzes the transformation of one micromole of substrate per minute under specified conditions.

2) Kidney function biomarker

a) Estimation of serum creatinine concentration

The level of serum creatinine concentration was measured according to previously established protocol [31, 32]. Briefly, $20 \mu \mathrm{l}$ serum sample or standard was mixed with $200 \mu \mathrm{l}$ reagent in a quartz cuvette. The absorbance of the sample and the standard against the reagent blank were measured at $510 \mathrm{~nm}$ at different time points (i.e., 30 and $120 \mathrm{sec}$ ). The concentration of creatinine in the sample was calculated by using software program with the following formula:

$$
\begin{aligned}
& \text { Creatinine concentration }\left(\frac{\mathrm{mg}}{\mathrm{dl}}\right) \\
& =\left\{(A 2-A 1) \frac{\text { sample }}{A 2-A 1} \text { standard }\right\} \times C \text { standard }
\end{aligned}
$$

Here, $A 1=$ Absorbance of sample at 30 seconds, $A 2=$ Absorbance of sample at 120 seconds, $C=$ Creatinine standard. All experiments were carried out in triplicate and the results were presented in the average measurements with standard deviation.

\subsection{Statistical Analysis}

The results were presented as the average measurements of the runs \pm Standard error mean (SEM). Data were subjected to statistical analysis using one-way analysis of variance (ANOVA) with GraphPad Prism 5.0 (GraphPad Software Inc., San Diego, CA). Post hoc test was determined by Dunnett test. The mean values were statistically significant at $\mathrm{p}<0.05$ [33]. All the analysis was carried out in triplicate (i.e., $n=3)$.

\section{RESULTS AND DISCUSSION}

\subsection{Antibacterial Activity Assay}

\subsubsection{Determination of MIC and ZOI}

The lowest concentration of an antibacterial agent that inhibits the visible growth of bacteria is 
known as minimum inhibitory concentration (MIC). Among all extracts, the lowest MIC value, $2 \mu \mathrm{g} / \mu \mathrm{l}$, was obtained for aqueous seed extract against Bacillus subtilis. For other extracts, the MIC value was within $2.5-5 \mu \mathrm{g} / \mu \mathrm{l}$ of concentration against the tested bacteria (Table 1 and Figure 1).

Table 1. Zone of inhibition (ZOI) and minimum inhibitory concentration (MIC) of different $D$. malabarica seed and flesh extracts after 2 hours of incubation.

\begin{tabular}{ccccc}
\hline & & \multicolumn{3}{c}{ Bacterial strains } \\
\cline { 3 - 5 } & Plant extracts & $\begin{array}{c}\text { Bacillus subtilis } \\
\text { RBW (Gram } \\
\text { positive) }\end{array}$ & $\begin{array}{c}\text { Escherichia coli } \\
\text { DH5a (Gram } \\
\text { negative) }\end{array}$ & $\begin{array}{c}\text { Salmonella } \\
\text { typhi (Gram } \\
\text { negative) }\end{array}$ \\
\hline Minimum & Aqueous seed & 2 & 2.5 & 2.5 \\
inhibitory & Aqueous flesh & 3.5 & 4 & 4.5 \\
concentration & Ethanolic seed & 4 & 4 & 4.5 \\
$(\mu g / \mu l)$ & Ethanolic flesh & 4 & 4 & 5 \\
Zone of & Aqueous flesh $(4 \mathrm{mg})$ & $9.74 \pm 0.11$ & $10.47 \pm 0.4$ & $10.48 \pm 0.4$ \\
Inhibition & Ethanolic seed $(4 \mathrm{mg})$ & $8.44 \pm 0.39$ & $8.25 \pm 0.05$ & $8.22 \pm 0.06$ \\
$(\mathbf{m m})$ & Ethanolic flesh $(4 \mathrm{mg})$ & $9.10 \pm 0.21$ & $8.05 \pm 0.17$ & $8.02 \pm 0.16$ \\
Mean \pm SEM & Negative control & $5.58 \pm 0.00$ & $5.56 \pm 0.002$ & $5.56 \pm 0.00$ \\
& $(0.9 \% \mathrm{NaCl})$ & & & \\
\hline
\end{tabular}
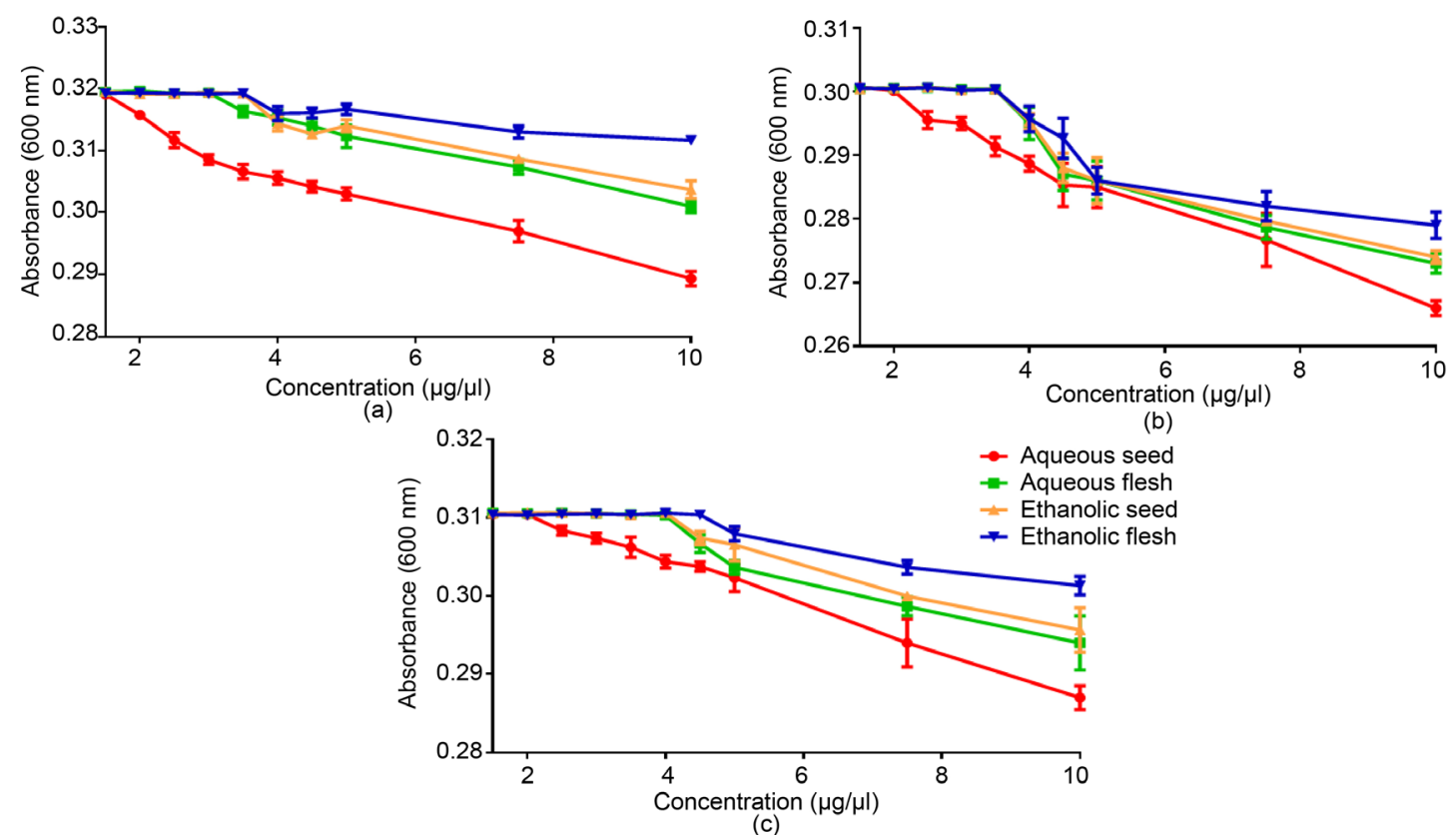

(c)

Figure 1. Absorbance of bacterial culture incubated for 2 hours in the presence of different amounts of $D$. malabarica seed and flesh extracts. The figures represent minimum inhibitory concentration (MIC) of $D$. malabarica seed and flesh extracts against $B$. subtilis (a), E. coli DH5a (b), and S. typhi (c). All the values are mean \pm SEM of three determinations $(n=3)$. 
The antibacterial activity of $D$. malabarica extracts in terms of zone of inhibition (ZOI) was also determined through measuring the diameter (in millimeter) of the clear zone surrounding the metrical filter paper disks at different time points (i.e., 1, 2, 3, 4, 5, 6, 7, 8, and 24 hours) as well as different doses (i.e., $0.2,1,2,3$, and $4 \mathrm{mg}$ ). The $\mathrm{ZOI}$ in the presence of $0.9 \% \mathrm{NaCl}$ (i.e., negative control) was also measured at the same time points. The highest ZOI was observed for all the extracts against all the tested bacterial strains after $2 \mathrm{~h}$ of the treatment and, thereafter, decreases gradually. More specifically, after 2 hours of incubation, the maximum antibacterial activity was observed for aqueous seed extract $(4 \mathrm{mg})$ against $B$. subtilis (i.e., $12.72 \mathrm{~mm}$ ), E. coli (i.e., $11.41 \mathrm{~mm}$ ), and S. typhi (i.e., $11.42 \mathrm{~mm}$ ) (Table 1). The aqueous flesh, ethanolic seed, and ethanolic flesh extracts showed mediocre ZOI (i.e., $8-11 \mathrm{~mm}$ ) against the tested bacteria (Table 1).

Studies on $D$. malabarica plant revealed that different parts of $D$. malabarica are the rich source of phytochemicals [13-15]. Recently, we have reported that D. malabarica seed and flesh extracts contain various phytochemicals including phenol, tannin, flavonoid, alkaloid, proteins, reducing sugar, glycosides, terpenoids, quinones and so on [16]. From the previous studies, it was found that these phytochemicals are responsible for preventing bacterial infection through different physiological functions [34]. For example: plant polyphenols, tannin, and flavonoids prevent bacteria through binding to adhesins, enzyme inhibition or inactivation, substrate deprivation, complexing with cell wall, membrane disruption, metal ion complexation and so on [12,34,35]. Alkaloids intercalate into cell wall and DNA of microbes [34]. Terpenoids, proteins, glycosides, and quinones are responsible for the disruption of membrane through binding with the cell surface adhesins which result in the formation of pores, and inactivation of enzymes [36]. Hence, the presence of these phytochemicals may provide $D$. malabarica extracts with their potent antibacterial activity.

\subsubsection{Trypan Blue Dye Exclusion Assay}

Trypan blue is a negatively charged dye that can't pass through the intact cell wall of live bacteria. Therefore, it is used to differentiate cell wall compromised dead bacteria from cell wall intact live bacteria [37]. Trypan blue dye exclusion assay was performed to confirm the antibacterial activity of $D$. malabarica fruit extracts against pathogenic as well as nonpathogenic bacteria. As the extracts contain phytochemicals (i.e., phenol, tannin, quinones, glycosides and so on) that are responsible for making complex with cell wall through hydrophobic interaction and membrane disruption $[12,35,36]$, they help to create pores on the lipid layer of membrane. As a result, the blue dye gets inside the bacteria treated with $D$. malabarica fruit extracts and appears blue under the phase contrast microscope (Figures 2-4) [25].

\subsubsection{CellTox ${ }^{\mathrm{TM}}$ Green Assay}

CellTox $^{\mathrm{TM}}$ Green is a fluorescent dye that binds to the DNA of cell wall compromised bacteria and emits green fluorescence. Therefore, it is used to distinguish live and dead bacteria [23, 38]. The fluorescence intensity of CellTox ${ }^{\mathrm{TM}}$ Green dye labelled dead bacteria was quantified using Spectrofluorophotometer (SHIMADZU RF-6000, Japan) at $490 \mathrm{~nm}$ (Figure 5) and the dead cells were also observed under a fluorescence microscope (Olympus BX50 Fluorescence Microscope, Olympus, Japan) (Figure 6). The fluorescence intensity of aqueous seed extract treated B. subtilis, E. coli, and $S$. typhi was significantly higher than that of the other extracts (Figure 5). Furthermore, the fluorescence intensity of aqueous seed extract treated B. subtilis and S. typhi was $\sim 6$ and $\sim 8$ folds, respectively, higher than that of the control (i.e., untreated bacteria).

\subsubsection{Lipid Peroxidation (LP0) Assay}

LPO assay was performed to determine the oxidation ability of $D$. malabarica seed and flesh extracts to bacterial cell membrane fatty acids $[23,25]$. As the oxidation of fatty acids brings about the disruption of cell membrane integrity, it can be an effective way to kill the bacteria [23, 24]. Hence, the cell membrane fatty acid oxidation potential of the $D$. malabarica extracts was investigated through measuring the absorbance of malondialdehyde-thiobarbituric acid (MDA-TBA) pink adduct at $532 \mathrm{~nm}$ (Figure 7). The higher 

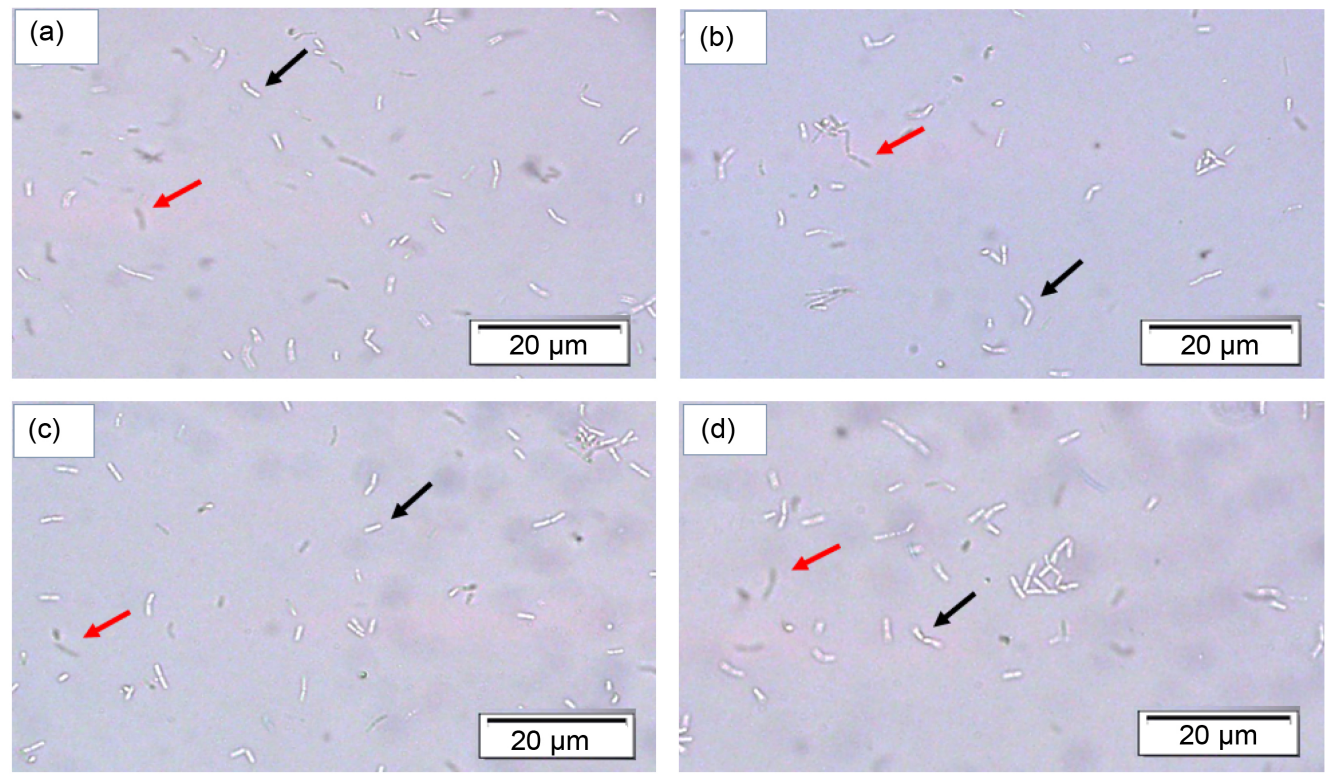

Figure 2. Trypan blue dye exclusion assay to investigate the bactericidal effect of $D$. malabarica extracts against $B$. subtilis using aqueous extract of seed (a), aqueous extract of flesh (b), ethanolic extract of seed (c), and ethanolic extract of flesh (d). Dead and live cells have been indicated with red and black colored arrows, respectively. The images were taken using a Phase Contrast Light Microscope at $(40 \times 1.25) \times$ magnification.
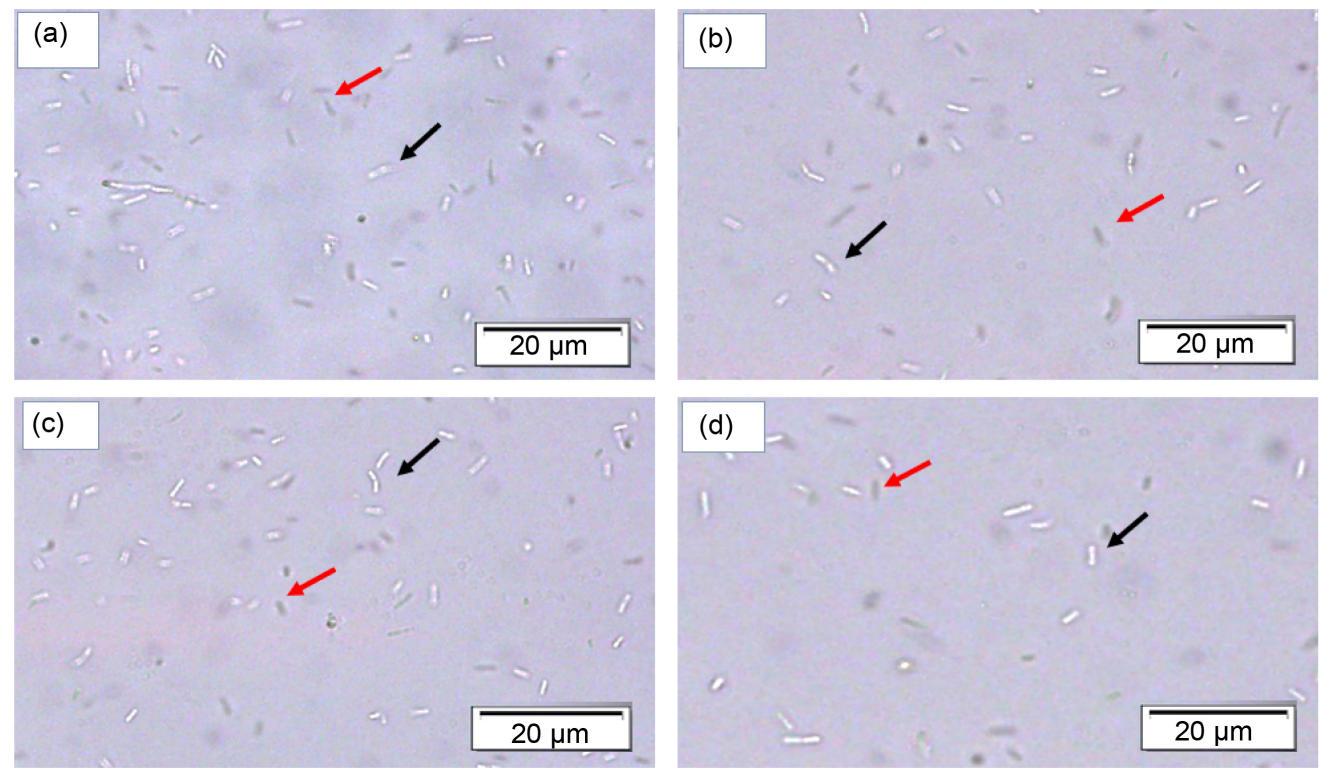

Figure 3. Trypan blue dye exclusion assay to investigate the bactericidal effect of $D$. malabarica extracts against $E$. coli $\mathrm{DH} 5 a$ using aqueous extract of seed (a), aqueous extract of flesh (b), ethanolic extract of seed (c), and ethanolic extract of flesh (d). Dead and live cells have been indicated with red and black colored arrows, respectively. The images were taken using a Phase Contrast Light Microscope at $(40 \times 1.25) \times$ magnification. 

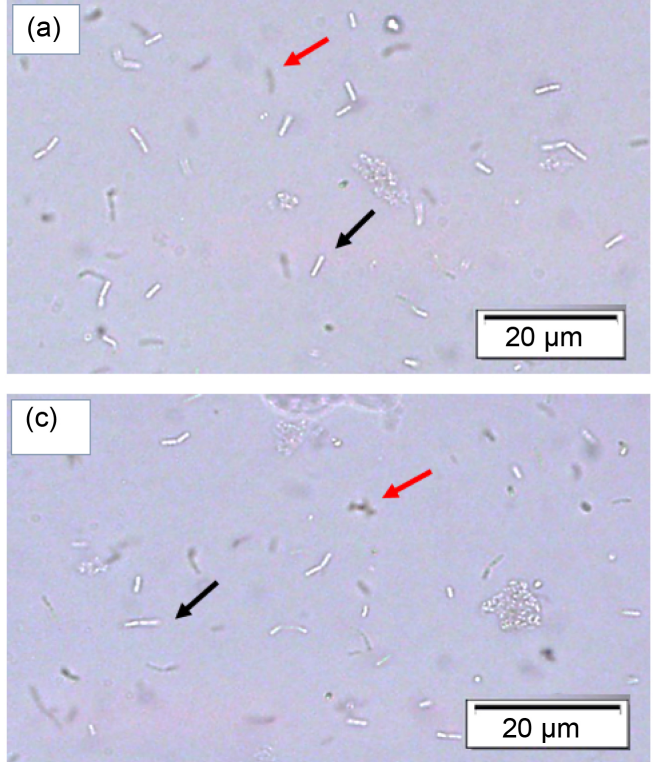

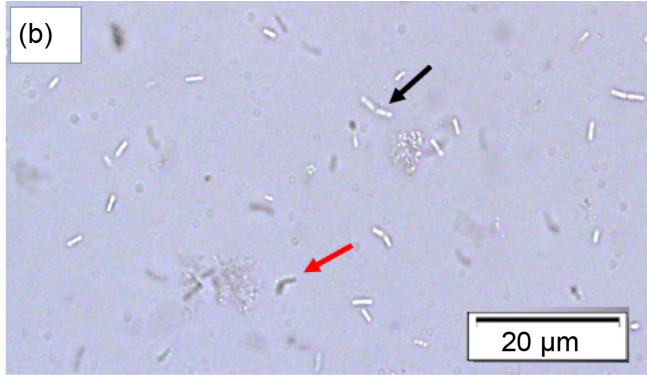

(d)

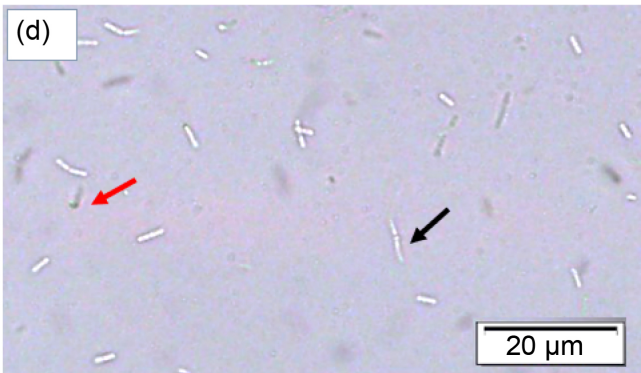

Figure 4. Trypan blue dye exclusion assay to investigate the bactericidal effect of $D$. malabarica extracts against $S$. typhi using aqueous extract of seed (a), aqueous extract of flesh (b), ethanolic extract of seed (c), and ethanolic extract of flesh (d). Dead and live cells have been indicated with red and black colored arrows, respectively. The images were taken using a Phase Contrast Light Microscope at $(40 \times 1.25) \times$ magnification.

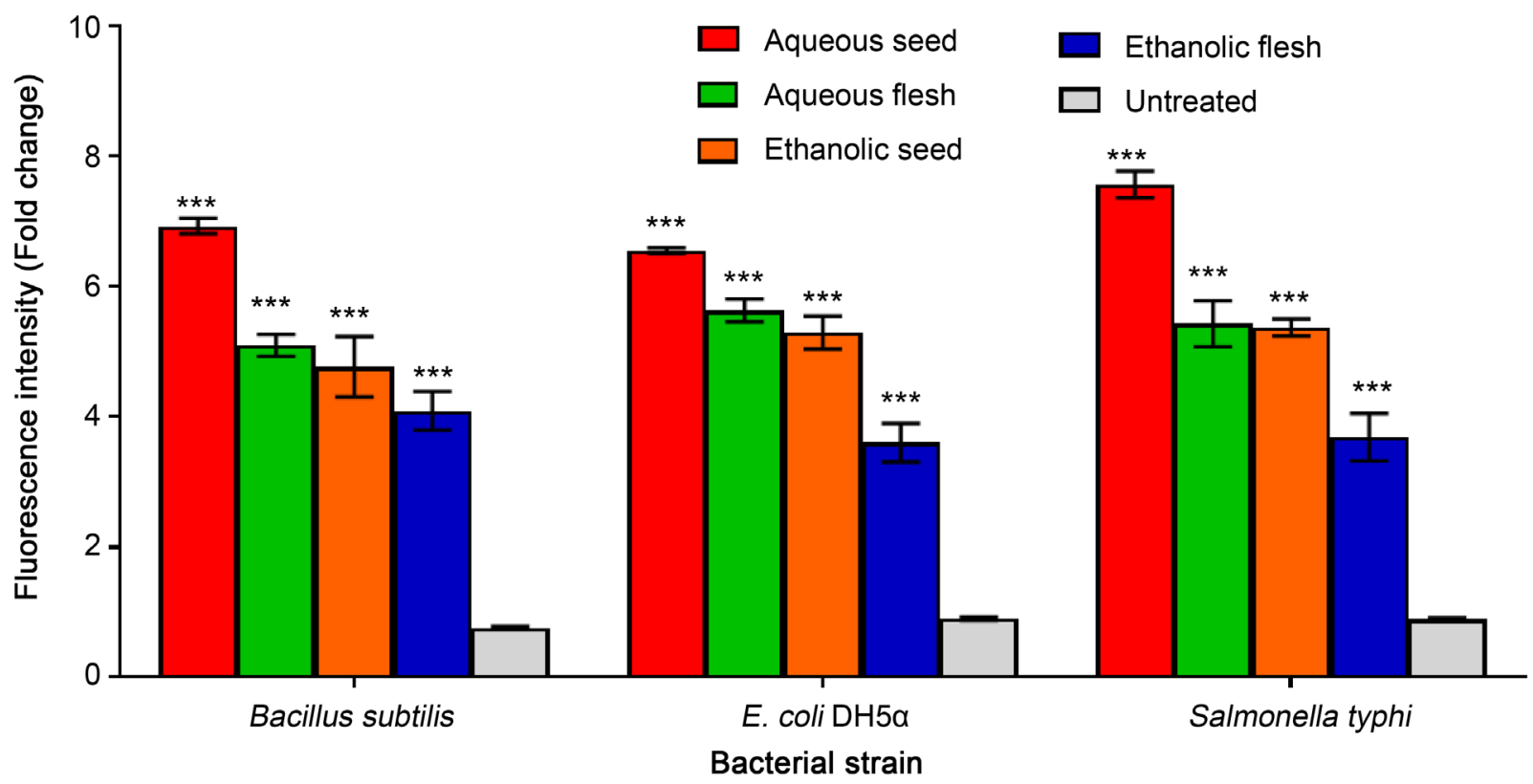

Figure 5. Cell Tox ${ }^{\mathrm{TM}}$ Green uptake assay. The fluorescence intensity of bacterial strains (i.e., $B$. subtilis, E. coli DH5a, and $S$. typhi) treated with of $D$. malabarica seed and flesh extracts was measured at $490 \mathrm{~nm}$ using a spectrofluorometer. The data have been presented as an average value of three replications \pm SEM $(n=3)$. Data were analyzed by GraphPad Prism 5.0 using ANOVA (Dunnett test) and significance level was determined $\left.{ }^{* * *} \mathrm{p}<0.001\right)$. 

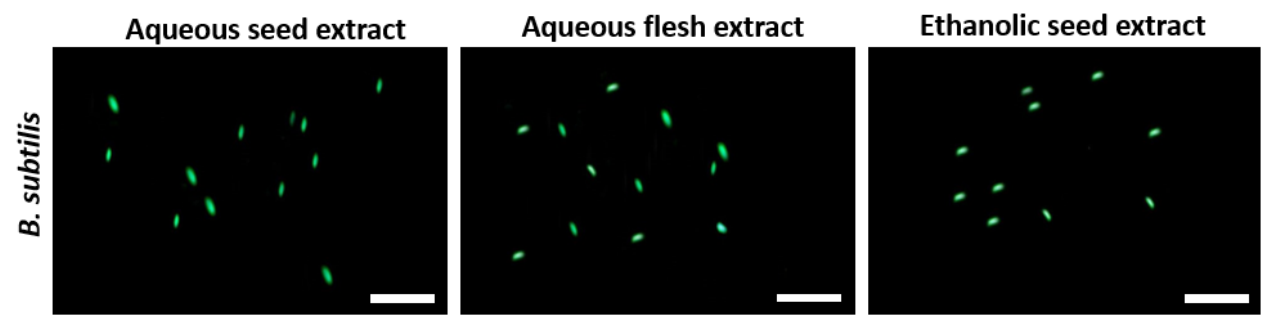

Ethanolic flesh extract
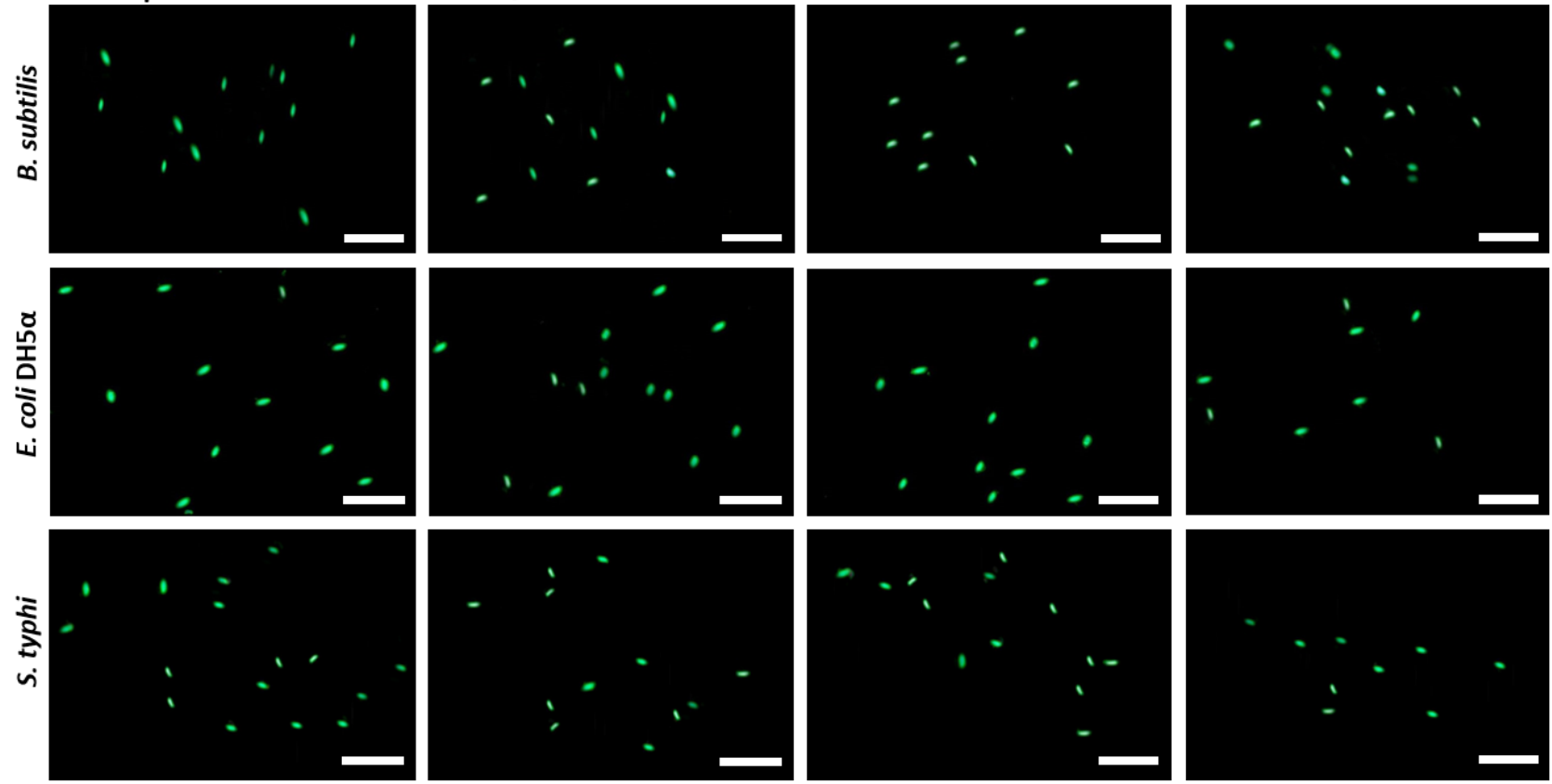

Figure 6. CellTox ${ }^{\mathrm{TM}}$ Green assay. B. subtilis, E. coli DH5a, and S. typhi were first treated with aqueous extract of seed, aqueous extract of flesh, ethanolic extract of seed, and ethanolic extract of flesh of $D$. malabarica. The treated bacteria were then incubated with CellTox ${ }^{\mathrm{TM}}$ green to stain the cell wall compromised bacterial DNA and green fluorescence was observed under a fluorescence microscope $(40 \times)$. Scale bar: $20 \mu \mathrm{m}$.

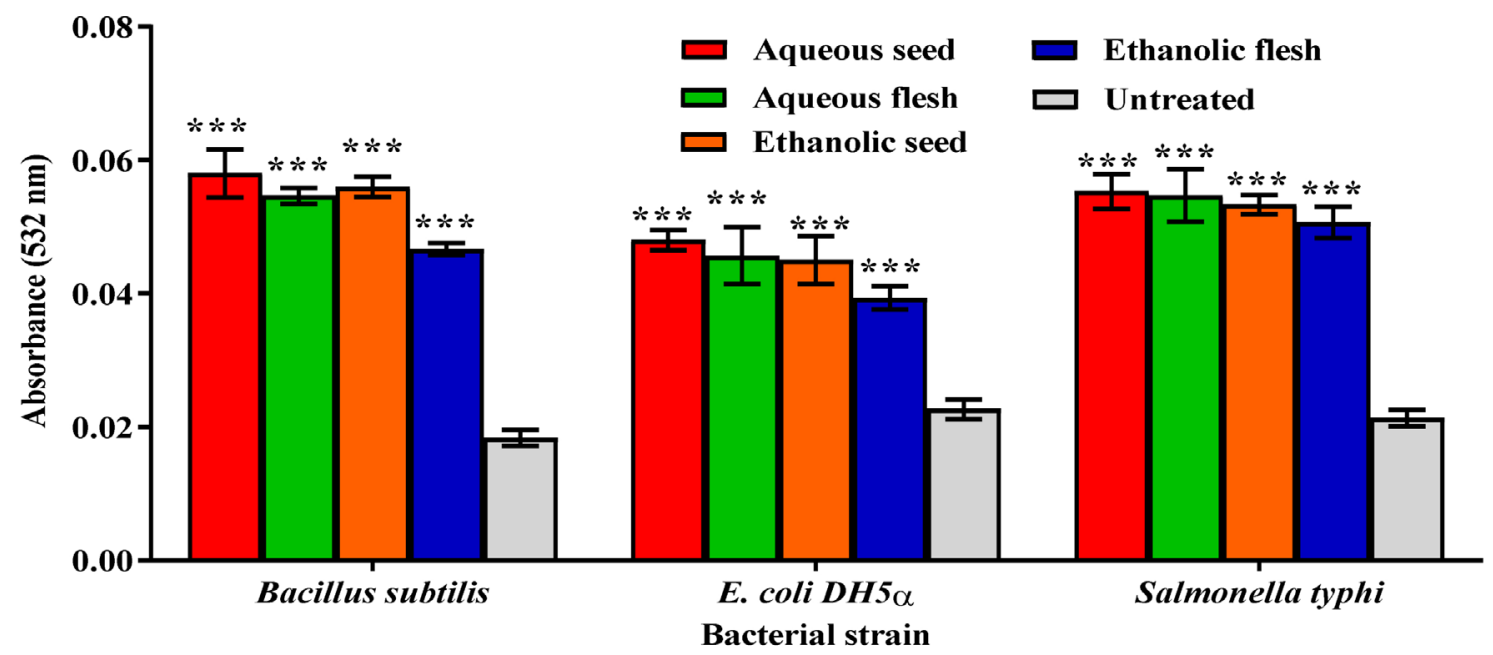

Figure 7. Lipid peroxidation assay of $D$. malabarica seed and flesh extracts against pathogenic (i.e., $S$. typhi) and nonpathogenic (i.e., B. subtilis and $E$. coli DH5a) bacteria. The cell membrane fatty acid oxidation potential of the plant extracts was measured through malondialdehyde-thiobar-bituric acid (MDA-TBA) adduct assay. The absorbance of MDA-TBA pink adduct was measured at $532 \mathrm{~nm}$ (i.e., $\lambda \max )$. The data have been presented as an average value of three replications \pm SEM $(n=3)$. Data were analyzed by GraphPad Prism 5.0 using ANOVA (Dunnett test) and significance level was determined $\left({ }^{* *} \mathrm{p}<0.001\right)$. 
the absorbance, the higher the fatty acid oxidation ability. The aqueous seed extract showed the highest fatty acid oxidation potential against all the tested bacteria and was significantly higher than that of the control (i.e., untreated bacteria) (Figure 7). However, these extracts are not effective as fatty acid oxidizers, since $D$. malabarica fruit extracts are rich in natural antioxidants [16]. Previous studies revealed that natural antioxidants might show pro-oxidant effects [39]. Therefore, due to the presence of pro-oxidant influences, $D$. malabarica fruit extracts showed minute amount of fatty acid oxidation potential to bacterial cell membrane fatty acids.

\subsection{Antifungal Activity Assay}

Antifungal activity of the polar extracts of $D$. malabarica seed and flesh were performed through poison food method against three pathogenic fungus (i.e., Pestalotiopsis microspore, Botrytis cinerea, and Fusarium oxysporum). No fungal growth was observed in PDA medium containing Propiconazole (i.e., positive control) and no inhibition was observed in PDA medium containing $0.9 \% \mathrm{NaCl}$ (i.e., negative control). The mycelial growth of $P$. microspore, B. cinerea, and $F$. oxysporum was $48.66 \mathrm{~mm}, 59.44 \mathrm{~mm}$, and $15.78 \mathrm{~mm}$, respectively, when grown in PDA medium containing $0.9 \% \mathrm{NaCl}$ (Table 2). Whereas, in aqueous seed extract, the highest mycelial growth was observed against $P$. microspore $(49.16 \mathrm{~mm})$ and in aqueous flesh extract, the highest mycelial growth was obtained against $B$. cinerea $(61.33 \mathrm{~mm})$, and $F$. oxysporum $(16 \mathrm{~mm})$ (Table 2$)$.

Percentage mycelial inhibition (PMI) was calculated to determine the antifungal activity of D. malabarica seed and flesh extracts. The higher the value of PMI, the higher the antifungal activity [8]. Aqueous extracts did not show any antifungal activity against $B$. cinerea and $F$. oxysporum. However, the ethanolic seed extract demonstrated the highest antifungal activity (i.e., PMI: 4.55) against B. cinerea (Table 2). The

Table 2. Mycelial growth and percentage mycelial inhibition (PMI) of D. malabarica seed and flesh extracts after 72 hours of incubation.

\begin{tabular}{|c|c|c|c|c|}
\hline & \multirow{2}{*}{ Plant extracts } & \multicolumn{3}{|c|}{ Fungal strains } \\
\hline & & \multicolumn{3}{|c|}{ Pestalotiopsis microspora Botrytis cinerea Fusarium oxysporum } \\
\hline \multirow{5}{*}{$\begin{array}{l}\text { Mycelial } \\
\text { growth (mm) } \\
\text { Mean } \pm \text { SEM }\end{array}$} & $\begin{array}{l}\text { (-)ve Control } \\
(0.9 \% \mathrm{NaCl})\end{array}$ & $48.66 \pm 0.51$ & $59.44 \pm 1.41$ & $15.78 \pm 1.11$ \\
\hline & Aqueous seed (10 mg) & $49.16 \pm 0.51$ & $61.33 \pm 0.69$ & $15.89 \pm 0.68$ \\
\hline & $\begin{array}{l}\text { Aqueous flesh } \\
(10 \mathrm{mg})\end{array}$ & $48.56 \pm 1.06$ & $61.33 \pm 1.92$ & $16 \pm 0.19$ \\
\hline & $\begin{array}{l}\text { Ethanolic seed } \\
(10 \mathrm{mg})\end{array}$ & $46.88 \pm 1.52$ & $56.73 \pm 2.12$ & $15.22 \pm 0.91$ \\
\hline & $\begin{array}{l}\text { Ethanolic flesh } \\
(10 \mathrm{mg})\end{array}$ & $46.79 \pm 0.99$ & $57.18 \pm 0.4$ & $15.33 \pm 0.33$ \\
\hline \multirow{4}{*}{$\begin{array}{l}\text { Percentage } \\
\text { mycelial } \\
\text { inhibition } \\
(\mathrm{PMI})(\%)\end{array}$} & Aqueous seed & No effect & No effect & No effect \\
\hline & Aqueous flesh & 0.23 & No effect & No effect \\
\hline & Ethanolic seed & 3.65 & 4.55 & 3.52 \\
\hline & Ethanolic flesh & 3.84 & 3.80 & 2.82 \\
\hline
\end{tabular}


ethanolic flesh extract also showed little antifungal activity against the tested fungi. Previously, it was reported that polar (i.e., methanolic) extract of $D$. malabarica fruit demonstrate antifungal activity at higher concentrations [15]. Therefore, ethanolic extracts of $D$. malabarica could be a natural and effective antifungal agent at higher concentrations.

\subsection{Hemocompatibility Assay}

Hemolytic potential of different concentrations (i.e., 1 - $4 \mathrm{mg}$ ) of D. malabarica seed and flesh extracts was performed using human and rat red blood cells (RBCs) to investigate their biocompatibility. All the extracts showed excellent hemocompatibility to human as well as rat RBCs (Figure 8(a) and Figure 8(b)). At the concentration of $4 \mathrm{mg}$, the ethanolic seed extract demonstrated the highest hemolytic activity (3.71\%) to human RBCs. On the other hand, the aqueous seed extract demonstrated the highest hemolytic activity $(4.41 \%)$ to rat RBCs. The hemolytic potential of $D$. malabarica fruit extracts was less than the acceptable hemolytic value (i.e., 5\%) that is considered as safe for the potential therapeutic applications [23]. The $\mathrm{HC}_{50}$ value (the amount required to lyse the $50 \%$ of RBCs) for aqueous and ethanolic extracts of $D$. malabarica seed and flesh was ranged from $50 \mathrm{mg}$ to $90 \mathrm{mg}$ which was $\sim 15$ times higher than that of the amount used for antibacterial activity assay (Figure 8(c)). As the interaction of plant extracts with RBCs provides primary information about their biocompatibility [1], it can be stated that $D$. malabarica seed and flesh extracts are highly biocompatible and could be safe as therapeutics.

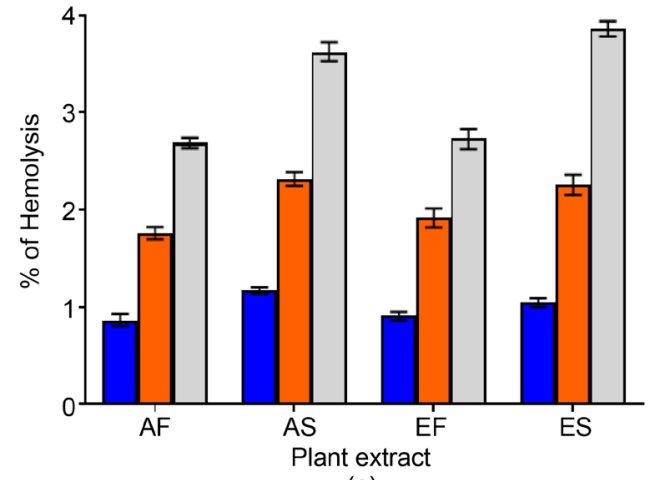

(a)

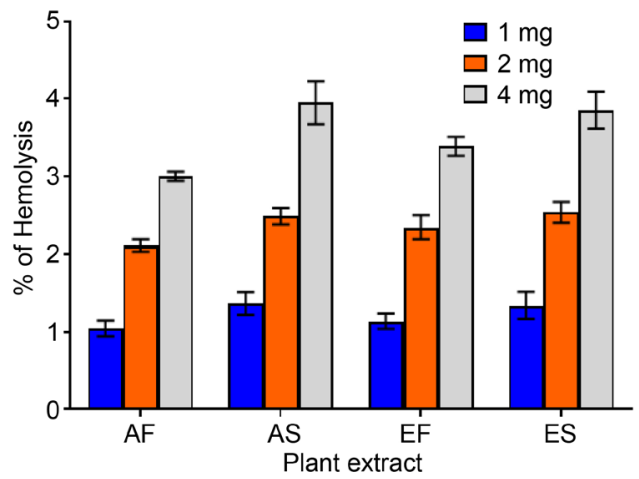

(b)

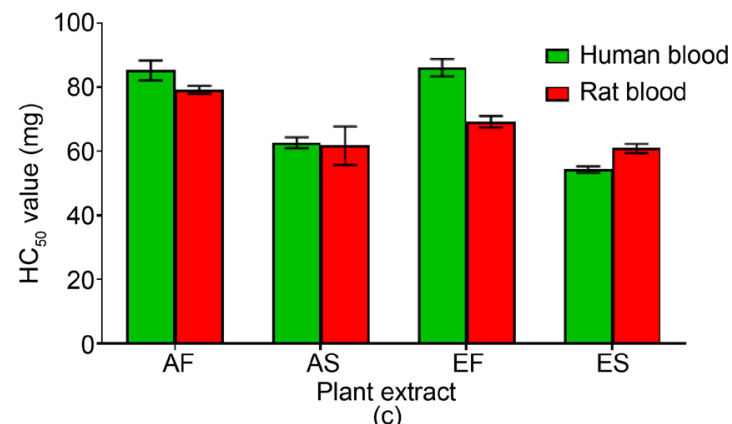

(c)

Figure 8. Hemocompatibility of $D$. malababarica seed and flesh extracts to Human (a) and Rat (b) red blood cells (RBCs). Different amounts (i.e., $1 \mathrm{mg}, 2 \mathrm{mg}$, and $4 \mathrm{mg}$ ) of D. malabarica seed and flesh extracts were taken in the hemocompatibility assay. Here, AF = aqueous flesh extract, AS = aqueous seed extract, EF = ethanolic flesh extract, and ES = ethanolic seed extract. (c) The amount of extracts at which $50 \%$ hemolysis of $\mathrm{RBCs}$ occurred $\left(\mathrm{HC}_{50}\right)$ was presented and no significant difference was observed between human and rat RBCs. The data have been presented as an average value of different replications \pm SEM $(n=3)$. Data were analyzed by GraphPad Prism 5.0 using ANOVA (Dunnett test) and no significant difference was observed ( $p>0.05)$. 


\subsection{Inhibition of $\mathrm{H}_{2} \mathrm{O}_{2}$ Mediated Hemolysis}

D. malabarica fruit extracts are rich in polyphenolics, flavonoids and vitamin $\mathrm{C}$ and are an excellent source of natural antioxidants [16]. Hence, the extracts prevent the generation of reactive oxygen species (ROS) (i.e., superoxide, singlet oxygen, and $\mathrm{H}_{2} \mathrm{O}_{2}$ etc.) that cause the oxidation of cellular protein, lipid and DNA. Figure 9 showed the ability of the D. malabarica seed and flesh extracts to prevent $\mathrm{H}_{2} \mathrm{O}_{2}$ induced hemolysis. Furthermore, the extracts can inhibit $\mathrm{H}_{2} \mathrm{O}_{2}$ induced hemolysis in a dose dependent manner (Figure 9(a)). The $\mathrm{IC}_{50}$ values of aqueous seed, aqueous flesh, ethanolic seed, and ethanolic flesh extracts were $2.58 \mathrm{mg}, 3.27 \mathrm{mg}, 2.67 \mathrm{mg}$, and $2.95 \mathrm{mg}$, respectively, and the $\mathrm{IC}_{50}$ value of ascorbic acid was $1.77 \mathrm{mg}$ (Figure 9(b)). The $\mathrm{IC}_{50}$ value of aqueous seed, aqueous flesh, ethanolic seed and ethanolic flesh was significant with respect to that of ascorbic acid (Figure 9(b)). The lowest $\mathrm{IC}_{50}$ value was obtained for aqueous seed extract (i.e., $2.58 \mathrm{mg}$ ) and is the most efficient free radical scavenger. Therefore, it can be said that $D$. malabarica fruit extracts are not only hemocompatible but also they can protect blood cells from degradation induced by reactive oxygen species (ROS).

\subsection{In Vivo Cytotoxicity Assay}

The aqueous extracts of $D$. malabarica seed and flesh were administered orally to rats for 14 days to investigate any toxic effects on animal tissues and organs. During this time, the rats were weighed every day and checked properly for any physiological changes (i.e., skin color, salivation, respiration rate and so on) and compared with that of untreated rats (i.e., control). The body weights increased gradually (Figure 10(a)), no physiological changes observed and all the experimental rats were alive (Table 3). After 14 days, the rats were sacrificed and the organs of the treated (i.e., administered with aqueous extracts of $D$. malabarica seed and flesh) and untreated (i.e., administered with PBS only) rats were weighed. No significant changes was observed in terms of the weight of organs of the treated rats when compared to that of untreated rats (Table 4 and Figures $10(\mathrm{~b})-(\mathrm{d})$ ).

To determine the toxic effects of the aqueous extracts of $D$. malabarica seed and flesh on liver and kidney, the level of serum ALT, AST, $\gamma$-GT enzymes (i.e., liver function biomarker) and creatinine (i.e., kidney function biomarker) of both the control and experimental rats were measured. Previous studies

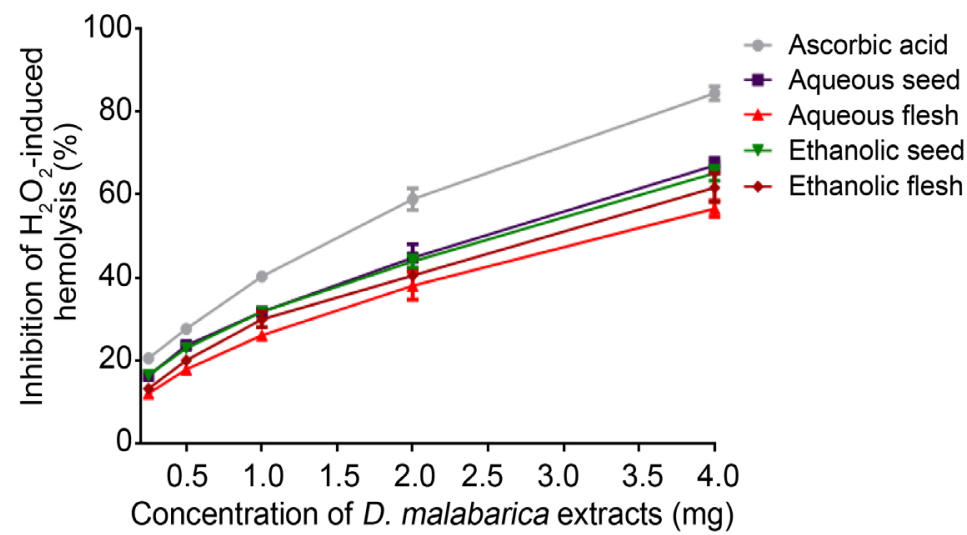

(a)

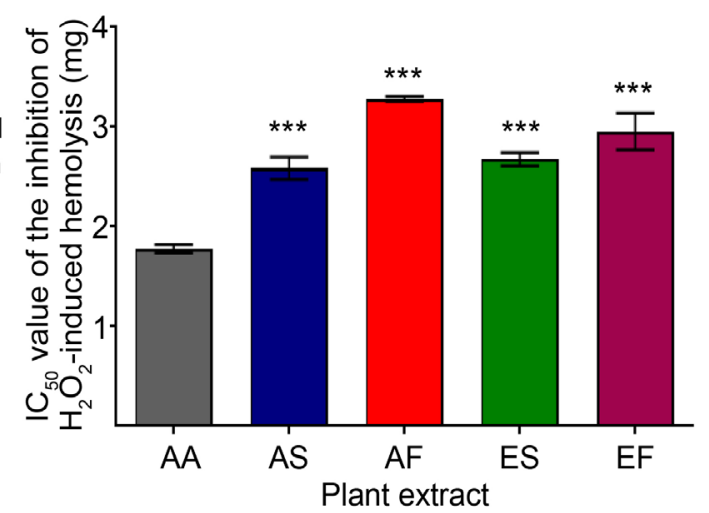

(b)

Figure 9. Percentage inhibition of $\mathrm{H}_{2} \mathrm{O}_{2}$ induced hemolysis by the plant extracts (a) and their $\mathrm{IC}_{50}$ values (b). Different amounts (i.e., $0.25 \mathrm{mg}, 0.5 \mathrm{mg}, 1 \mathrm{mg}, 2 \mathrm{mg}$, and $4 \mathrm{mg}$ ) of control (i.e., ascorbic acid) and $D$. malabarica seed and flesh extracts were taken in this assay. Here, AA = ascorbic acid, $\mathrm{AF}=$ aqueous flesh extract, $\mathrm{AS}=$ aqueous seed extract, $\mathrm{EF}=$ ethanolic flesh extract, and ES = ethanolic seed extract. The data have been presented an average value of different replications \pm SEM $(\mathrm{n}=$ 3). Data were analyzed by GraphPad Prism 5.0 using ANOVA (Dunnett test) and significance level was determined $\left({ }^{* * *} \mathrm{p}<0.001\right)$. 


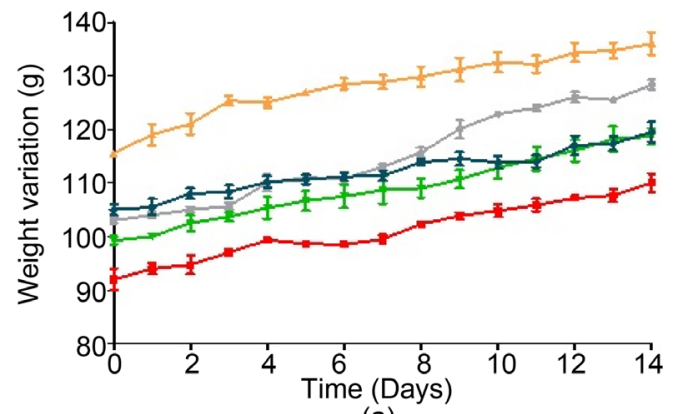

(a)

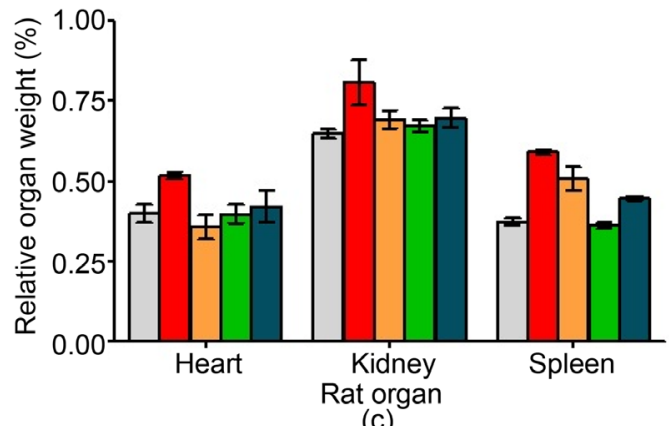

(c)

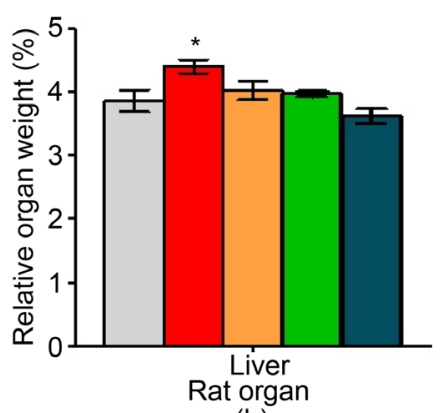

(b)

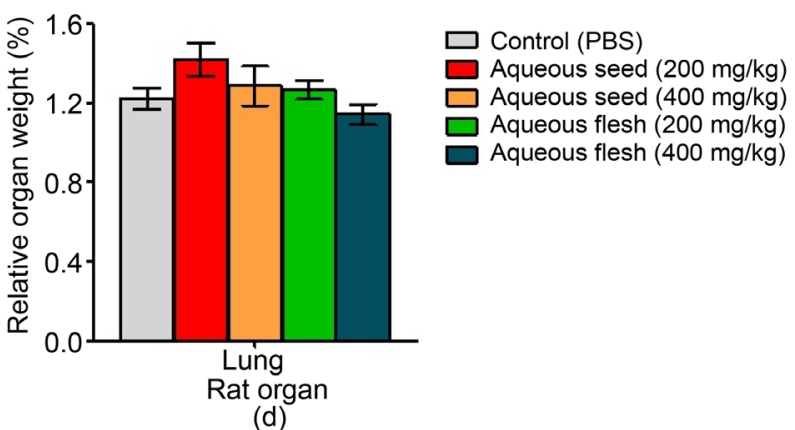

Figure 10. Body weight (a), relative organ weight of liver (b), relative organ weight of heart, kidney, and spleen (c) and relative organ weight of lung (d) of rats after feeding the aqueous extract of $D$. malabarica seed and flesh for 14 days. The values presented are mean \pm SEM of multiple samples (3 animals per group). Data were analyzed by GraphPad Prism 5.0 (GraphPad software) using one way ANOVA test. Dunnett test was used for post hoc comparison and significance level was determined $\left({ }^{*} \mathrm{p}<0.05\right)$.

Table 3. General appearance and behavioral observations for control and treated groups fed with aqueous extracts of $D$. malabarica seed and flesh.

\begin{tabular}{|c|c|c|c|c|c|}
\hline \multirow[b]{2}{*}{ Parameters } & \multirow{2}{*}{$\begin{array}{l}\text { Control } \\
\text { Only PBS }\end{array}$} & \multicolumn{4}{|c|}{ Treatment } \\
\hline & & $\begin{array}{l}\text { Aqueous seed } \\
(200 \mathrm{mg} / \mathrm{kg})\end{array}$ & $\begin{array}{l}\text { Aqueous seed } \\
(400 \mathrm{mg} / \mathrm{kg})\end{array}$ & $\begin{array}{l}\text { Aqueous flesh } \\
(200 \mathrm{mg} / \mathrm{kg})\end{array}$ & $\begin{array}{c}\text { Aqueous flesh } \\
(400 \mathrm{mg} / \mathrm{kg})\end{array}$ \\
\hline Skin and fur & No effect & No effect & No effect & No effect & No effect \\
\hline Eyes & Normal & Normal & Normal & Normal & Normal \\
\hline Mucus membrane & Normal & Normal & Normal & Normal & Normal \\
\hline Behavioral patterns & Normal & Normal & Normal & Normal & Normal \\
\hline Salivation & Normal & Normal & Normal & Normal & Normal \\
\hline Lethargy & Normal & Normal & Normal & Normal & Normal \\
\hline Sleep & Normal & Normal & Normal & Normal & Normal \\
\hline Respiration & Normal & Normal & Normal & Normal & Normal \\
\hline Urination (color) & Normal & Normal & Normal & Normal & Normal \\
\hline Feces (color) & Normal & Normal & Normal & Normal & Normal \\
\hline Diarrhea & Not observed & Not observed & Not observed & Not observed & Not observed \\
\hline Coma & Not observed & Not observed & Not observed & Not observed & Not observed \\
\hline Mortality & Alive & Alive & Alive & Alive & Alive \\
\hline
\end{tabular}


Table 4. Effects of oral administration of aqueous extracts of $D$. malabarica seed and flesh on the average weight $(\mathrm{g})$ of rat organs.

\begin{tabular}{|c|c|c|c|c|c|}
\hline \multirow{3}{*}{ Organ } & \multicolumn{5}{|c|}{ Average organ weight (g) } \\
\hline & \multicolumn{5}{|c|}{ Treatment } \\
\hline & $\begin{array}{l}\text { Control } \\
\text { (PBS) }\end{array}$ & $\begin{array}{l}\text { Aqueous seed } \\
(200 \mathrm{mg} / \mathrm{kg})\end{array}$ & $\begin{array}{l}\text { Aqueous seed } \\
(400 \mathrm{mg} / \mathrm{kg})\end{array}$ & $\begin{array}{l}\text { Aqueous flesh } \\
(200 \mathrm{mg} / \mathrm{kg})\end{array}$ & $\begin{array}{c}\text { Aqueous flesh } \\
(400 \mathrm{mg} / \mathrm{kg})\end{array}$ \\
\hline Heart & $0.51 \pm 0.03$ & $0.57 \pm 0.01$ & $0.49 \pm 0.04$ & $0.47 \pm 0.03$ & $0.50 \pm 0.05$ \\
\hline Kidney & $0.83 \pm 0.01$ & $0.88 \pm 0.06$ & $0.94 \pm 0.03$ & $0.80 \pm 0.02$ & $0.83 \pm 0.03$ \\
\hline Liver & $4.95 \pm 0.17$ & $5.24 \pm 0.07$ & $5.46 \pm 0.15$ & $4.71 \pm 0.05$ & $4.32 \pm 0.11$ \\
\hline Spleen & $0.48 \pm 0.01$ & $0.65 \pm 0.006$ & $0.69 \pm 0.04$ & $0.42 \pm 0.009$ & $0.53 \pm 0.007$ \\
\hline Lung & $1.56 \pm 0.05$ & $1.56 \pm 0.08$ & $1.74 \pm 0.11$ & $1.49 \pm 0.04$ & $1.36 \pm 0.05$ \\
\hline $\begin{array}{c}\text { Average body } \\
\text { weight }\end{array}$ & $128.33 \pm 0.72$ & $110 \pm 1.41$ & $136 \pm 1.69$ & $118.67 \pm 1.18$ & $119.5 \pm 1.54$ \\
\hline
\end{tabular}

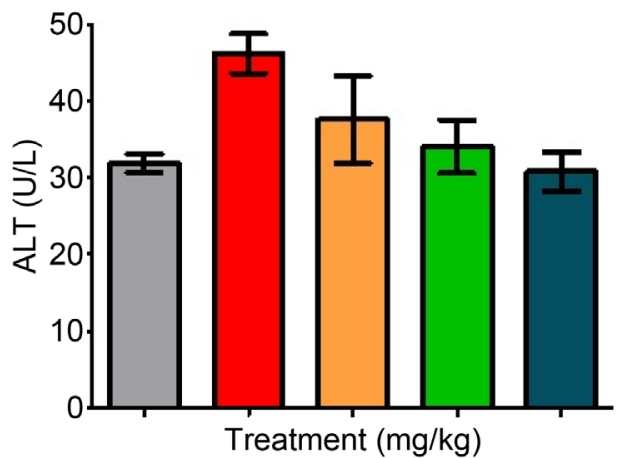

(a)

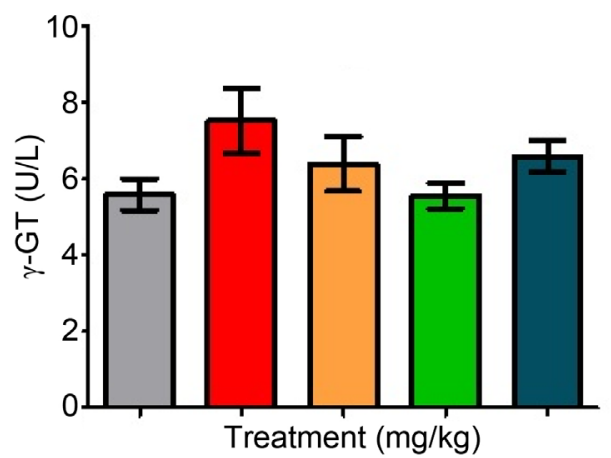

(c)

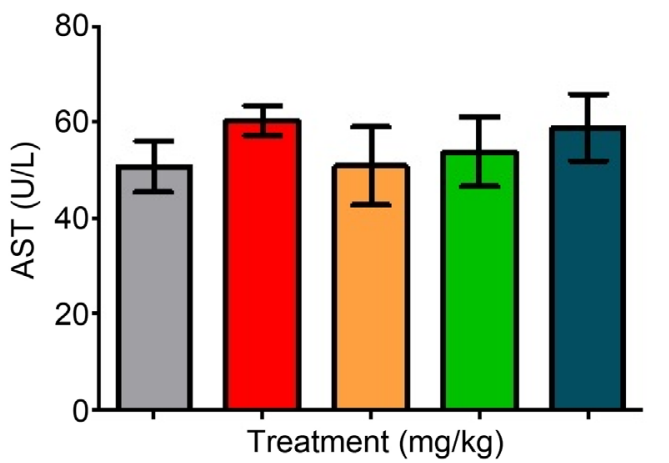

(b)

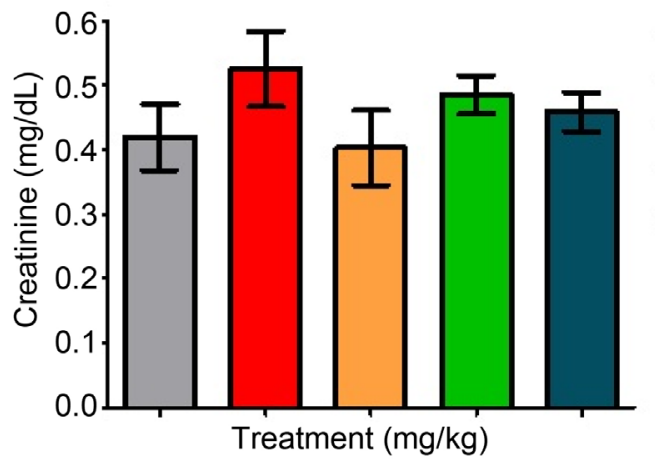

(d)

Figure 11. In vivo cytotoxicity assay. The effect of aqueous extracts of $D$. malabarica seed and flesh on liver function was investigated by measuring the levels of serum ALT (a), AST (b) and $\gamma$-GT (c). One the other hand, the effects of aqueous extracts of $D$. malabarica seed and flesh on kidney functions was investigated by measuring the level of serum creatinine $(d)$. The values presented are mean \pm SE of multiple samples (3 animals per group). Data were analyzed by GraphPad Prism 5.0 (GraphPad software) using one way ANOVA test. Dunnett test was used for posthoc comparison. No significant difference was observed ( $p>0.05$ ). 
revealed that the level of ALT, AST, and $\gamma$-GT enzymes increased whenever there is any damage in liver due to the decrease of ATP (a high-energy phosphate compound) or any impairment of the bile flow [23, $40,41]$. On the other hand, the increased level of creatinine indicates the inability of kidney to filter the waste product from blood [23, 42]. In this study, no significant differences was found in the level of serum ALT, AST, $\gamma$-GT enzymes and creatinine between experimental and control rats (Figures 11(a)-(d)). This indicates that $D$. malabarica seed and flesh extracts have no significant toxicity to liver as well as kidney and aqueous extracts of $D$. malabarica seed and flesh are safe for therapeutic applications.

\section{CONCLUSION}

The antimicrobial activity of $D$. malabarica fruit extracts was investigated in terms of their antibacterial activity as well as antifungal activity. The bactericidal effect of $D$. malabarica extracts was the highest after $2 \mathrm{~h}$ of incubation against all the bacterial strains in disk diffusion assay. On the other hand, the ethanolic extract showed slight antifungal activity against the pathogenic fungi. They showed excellent hemocompatibility and did not show any significant toxicity to rat liver and kidneys even at a high dose.

Therefore, it can be concluded that the aqueous and ethanolic extracts of $D$. malabarica fruit have moderate antibacterial propensity and excellent biocompatibility.

\section{ACKNOWLEDGEMENTS}

This research project was supported by Jahangirnagar University Research Grant 2017-18, Savar, Dhaka-1342, Bangladesh and University Grants Commission-Jahangirnagar University research grant 2017-18, Govt. of Bangladesh. The authors acknowledge Wazed Miah Science Research Center of Jahangirnagar University, Bangladesh, for allowing the use of their comprehensive facilities and services.

\section{CONFLICTS OF INTEREST}

The authors have no conflict of interests.

\section{REFERENCES}

1. Kumar, G., Karthik, L. and Rao, K.V.B. (2011) Hemolytic Activity of Indian Medicinal Plants towards Human Erythrocytes: An in Vitro Study. Elixir Applied Botany, 40, 5534-5537. https://www.elixirpublishers.com/articles/1350647393 40\%20(2011)\%205534-5537.pdf

2. Karimi, A., Majlesi, M. and Rafieian-Kopaei, M. (2015) Herbal versus Synthetic Drugs; Beliefs and Facts. Journal of Nephropharmacology, 4, 27. https://www.ncbi.nlm.nih.gov/pmc/articles/PMC5297475

3. Mahady, G.B. (2005) Medicinal Plants for the Prevention and Treatment of Bacterial Infections. Current Pharmaceutical Design, 11, 2405-2427. https://doi.org/10.2174/1381612054367481

4. Wadud, A., Prasad, P.V., Rao, M.M. and Narayana, A. (2007) Evolution of Drug: A Historical Perspective. Bulletin of the Indian Institute of History of Medicine (Hyderabad), 37, 69-80. http://ccras.nic.in/sites/default/files/viewpdf/jimh/BIIHM 2007/69\%20to\%2080.pdf

5. Li, X., et al. (2014) Functional Gold Nanoparticles as Potent Antimicrobial Agents against Multi-Drug-Resistant Bacteria. ACS Nano, 8, 10682-10686. https://doi.org/10.1021/nn5042625

6. Boxall, A.B. (2004) The Environmental Side Effects of Medication. EMBO Reports, 5, 1110-1116. https://doi.org/10.1038/sj.embor.7400307

7. Polash, S.A., Hossain, M.M., Saha, T. and Sarker, S.R. (2021) Biogenic Silver Nanoparticles: A Potent Therapeutic Agent. In: Emerging Trends in Nanomedicine, Springer, Berlin, 81-127.

https://doi.org/10.1007/978-981-15-9920-0 4

8. Mohana, D.C. and Raveesha, K.A. (2007) Anti-Fungal Evaluation of Some Plant Extracts against Some Plant 
Pathogenic Field and Storage Fungi. Journal of Agricultural Technology, 4, 119-137.

http://www.ijat-aatsea.com/pdf/june v4 n1 08/ijat2008 11 raveesha.pdf

9. Rahman, M.H. and Uddin, M.J. (2017) BLAST: A Threat to Cereal Crops in Bangladesh. Barisal University Journal Part 1, 4, 237-260. http://bu.ac.bd/uploads/BUI1V4I2/2.\%20Hasinur\%20Rahman.pdf

10. Harris, C.A., Renfrew, M.J. and Woolridge, M.W. (2001) Assessing the Risks of Pesticide Residues to Consumers: Recent and Future Developments. Food Additives \& Contaminants, 18, 1124-1129. https://doi.org/10.1080/02652030110050122

11. Saleem, U., et al. (2017) Acute oral Toxicity Evaluation of Aqueous Ethanolic Extract of Saccharum munja Roxb. Roots in Albino Mice as per OECD 425 TG. Toxicology Reports, 4, 580-585. https://doi.org/10.1016/j.toxrep.2017.10.005

12. Koley, H., Howlader, D.R. and Bhaumik, U. (2019) Assessment of Antimicrobial Activity of Different Phytochemicals against Enteric Diseases in Different Animal Models. In: New Look to Phytomedicine, Academic Press, Cambridge, 563-580. https://doi.org/10.1016/B978-0-12-814619-4.00022-7

13. Gratiana, E., Tenggara, N. and Jøker, D. (2004) Diospyros malabarica (Desr.) Kostel. Seed Leaflet, (105). https://curis.ku.dk/ws/files/20546962/105_diospyros_int.pdf

14. Ravikumar, A., Vengalrao, P., Shobhana, K. and Kishore, S. (2014) An Overview on Diospyros malabarica. IJNTPS, 4, 93-96. http://www.ijntps.com/sites/default/files/IntJNTPharmSci-4-5-93.pdf

15. Kaushik, V., Saini, V., Pandurangan, A., Khosa, R.L. and Parcha, V. (2012) A Review of Phytochemical and Biological Studies of Diospyros malabarica. International Journal of Pharmaceutical Sciences Letters, 2, 167-169. https://www.researchgate.net/profile/Dr Pandurangan/publication/263657168 A review of Phytochemical an d biological studies of Diospyros malabarica/links/55f39ba308ae1d980394a4b6.pdf

16. Shubhra, R.D., et al. (2019) Investigation of the Phytoconstituents and Antioxidant Activity of Diospyros malabarica Fruit Extracts. Advances in Bioscience and Biotechnology, 10, 431-454.

https://doi.org/10.4236/abb.2019.1012031

17. Mondal, R. (2017) Investigation of the Phytoconstituents and Bioactivityof Various Parts of Wild Type and Cultivated Phyllanthus emblica L. Advances in Bioscience and Biotechnology, 8, 211-227.

http://www.scirp.org/journal/PaperInformation.aspx?paperID=77426

https://doi.org/10.4236/abb.2017.87016

18. Polash, S.A., Saha, T., Hossain, M.S. and Sarker, S.R. (2017) Investigation of thePhytochemicals, Antioxidant, and Antimicrobial Activity of the Andrographis paniculata Leaf and Stem Extracts. Advances in Bioscience and Biotechnology, 8, 149-162. https://file.scirp.org/pdf/ABB 2017052315481908.pdf https://doi.org/10.4236/abb.2017.85012

19. Polash, S.A., Saha, T., Hossain, M.S. and Sarker, S.R. (2017) Phytochemical Contents, Antioxidant and Antibacterial Activity of the Ethanolic Extracts of Centellaasiatica (L.) Urb. Leaf and Stem. Jahangirnagar University Journal of Biological Sciences, 6, 51-57. https://doi.org/10.3329/jujbs.v6i1.33731

20. Azwanida, N.N. (2015) A Review on the Extraction Methods Use in Medicinal Plants, Principle, Strength and Limitation. Medicinal and Aromatic Plants, 4, 196.

21. Saha, T., et al. (2021) Nanodiamond-Chitosan Functionalized Hernia Mesh for Biocompatibility and Antimicrobial Activity. Journal of Biomedical Materials Research Part A. https://doi.org/10.1002/jbm.a.37237

22. Mizielińska, M., Salachna, P., Ordon, M. and Łopusiewicz, Ł. (2017) Antimicrobial Activity of Water and Acetone Extracts of Some Eucomis taxa. Asian Pacific Journal of Tropical Medicine, 10, 892-895. https://doi.org/10.1016/j.apjtm.2017.08.018

23. Hossain, M.M., et al. (2019) Investigation of the Antibacterial Activity and in Vivo Cytotoxicity of Biogenic Sil- 
ver Nanoparticles as Potent Therapeutics. Frontiers in Bioengineering and Biotechnology, 7, 239. https://doi.org/10.3389/fbioe.2019.00239

24. Niloy, M.S., et al. (2020) Synthesis of Biogenic Silver Nanoparticles Using Caesalpinia digyna and Investigation of Their Antimicrobial Activity and in Vivo Biocompatibility. ACS Applied BioMaterials, 3, 7722-7733. https://doi.org/10.1021/acsabm.0c00926

25. Ranjan Sarker, S., et al. (2019) Functionalization of Elongated Tetrahexahedral Au Nanoparticles and Their Antimicrobial Activity Assay. ACS Applied Materials \& Interfaces, 11, 13450-13459. https://doi.org/10.1021/acsami.9b02279

26. Pareja, E., et al. (2017) Inhibition of Erythrocyte Hemolysis Induced by $\mathrm{H}_{2} \mathrm{O}_{2}$ with Mangifera indica L. Extract. VII Latin American Congress on Biomedical Engineering CLAIB 2016, Bucaramanga, 26-28 October 2016, 457-460. https://link.springer.com/chapter/10.1007/978-981-10-4086-3 115 https://doi.org/10.1007/978-981-10-4086-3 115

27. OECD (2008) Test No. 425: Acute Oral Toxicity: Up-and-Down Procedure, OECD Guidelines for the Testing of Chemicals, Section 4. OECD Publishing, Paris.

28. Schumann, G. and Klauke, R.J. (2003) New IFCC Reference Procedures for the Determination of Catalytic Activity Concentrations of Five Enzymes in Serum: Preliminary Upper Reference Limits Obtained in Hospitalized Subjects. Clinica Chimica Acta, 327, 69-79. https://doi.org/10.1016/S0009-8981(02)00341-8

29. Bergmeyer, H., Scheibe, P. and Wahlefeld, A. (1978) Optimization of Methods for Aspartate Aminotransferase and Alanine Aminotransferase. Clinical Chemistry, 24, 58-73. https://doi.org/10.1093/clinchem/24.1.58

30. Szasz, G. (1969) A Kinetic Photometric Method for Serum $\gamma$-Glutamyl transpeptidase. Clinical Chemistry, 15, 124-136. https://doi.org/10.1093/clinchem/15.2.124

31. Bowers, L.D. and Wong, E.T. (1980) Kinetic Serum Creatinine Assays. II. A Critical Evaluation and Review. Clinical Chemistry, 26, 555-561. https://doi.org/10.1093/clinchem/26.5.555

32. Fabiny, D.L. and Ertingshausen, G. (1971) Automated Reaction-Rate Method for Determination of Serum Creatinine with the CentrifiChem. Clinical Chemistry, 17, 696-700. https://doi.org/10.1093/clinchem/17.8.696

33. Adeyemi, O.S. and Adewumi, I. (2014) Biochemical Evaluation of Silver Nanoparticles in Wistar Rats. International Scholarly Research Notices, 2014, Article ID: 196091. https://doi.org/10.1155/2014/196091

34. Mazid, M., Khan, T.A. and Mohammad, F. (2011) Role of Secondary Metabolites in Defense Mechanisms of Plants. Biology and Medicine, 3, 232-249.

https://www.longdom.org/open-access/role-of-secondary-metabolites-in-defense-mechanisms-of-plants-0974-8 369-3-128.pdf

35. Das, K., Tiwari, R.K.S. and Shrivastava, D.K. (2010) Techniques for Evaluation of Medicinal Plant Products as Antimicrobial Agent: Current Methods and Future Trends. Journal of Medicinal Plants Research, 4, 104-111. https://academicjournals.org/journal/JMPR/article-full-text-pdf/7B1A27415011

36. Wallace, R.J. (2004) Antimicrobial Properties of Plant Secondary Metabolites. Proceedings of the Nutrition Society, 63, 621-629. https://doi.org/10.1079/PNS2004393

37. Tran, S.L., Puhar, A., Ngo-Camus, M. and Ramarao, N. (2011) Trypan Blue Dye Enters Viable Cells Incubated with the Pore-Forming Toxin HlyII of Bacillus cereus. PLoS ONE, 6, e22876.

https://doi.org/10.1371/journal.pone.0022876

38. Zhang, J.H., Chung, T.D. and Oldenburg, K.R. (1999) A Simple Statistical Parameter for Use in Evaluation and Validation of High throughput Screening Assays. Journal of Biomolecular Screening, 4, 67-73. https://doi.org/10.1177/108705719900400206

39. Özen, B.Ö. and Soyer, A. (2018) Effect of Plant Extracts on Lipid and Protein Oxidation of Mackerel (Scomber 
scombrus) Mince during Frozen Storage. Journal of Food Science and Technology, 55, 120-127.

https://doi.org/10.1007/s13197-017-2847-6

40. Gupta, R.C. and Goad, J.T. (2000) Role of High-Energy Phosphates and Their Metabolites in Protection of Carbofuran-Induced Biochemical Changes in Diaphragm Muscle by Memantine. Archives of Toxicology, 74, 13-20. https://doi.org/10.1007/s002040050646

41. Ramaiah, S.K. (2007) A Toxicologist Guide to the Diagnostic Interpretation of Hepatic Biochemical Parameters. Food and Chemical Toxicology, 45, 1551-1557. https://doi.org/10.1016/j.fct.2007.06.007

42. Kaur, B., Khera, A. and Sandhir, R. (2012) Attenuation of Cellular Antioxidant Defense Mechanisms in Kidney of Rats Intoxicated with Carbofuran. Journal of Biochemical and Molecular Toxicology, 26, 393-398.

https://doi.org/10.1002/jbt.21433 